\title{
Neurons on the Move: Migration and Lamination of Cortical Interneurons
}

\author{
Clare Faux ${ }^{a}$ Sonja Rakic ${ }^{c}$ William Andrews ${ }^{c}$ Joanne M. Britto ${ }^{a, b}$ \\ ${ }^{a}$ Centre for Neuroscience, University of Melbourne, and ${ }^{b}$ Howard Florey Institute, Florey Neuroscience Institutes, \\ Parkville, Vic., Australia; ' Department of Cell and Developmental Biology, University College London, London, UK
}

\section{Key Words}

Interneuron · Cortical plate · Subtype specification •

Migration $\cdot$ Lamination genitors found in human and non-human primates and illustrate how the disruption of early developmental events can instigate a loss in GABAergic function.

Copyright $\odot 2012$ S. Karger AG, Basel

\section{Introduction}

The neocortex is the part of the brain involved in highlevel cognitive functions, and its expansion is regarded as a major evolutionary modification that led to the emergence of intelligence $[1,2]$. These processes are achieved through the cellular balance between neuronal excitation and inhibition within cortical circuits. The pyramidal neurons act primarily through the axonal release of the neurotransmitter glutamate to excite cortical and noncortical targets. In contrast, the majority of inhibitory neurons (interneurons) project locally to arborize in the same or multiple cortical columns [3,4], and a small number can extend long-range projections into remote cortical areas [5]. This highly diverse neuronal population modulates the output of excitatory pyramidal activity through the actions of the inhibitory neurotransmitter, $\gamma$-aminobutyric acid (GABA). Throughout embryonic and postnatal stages, GABA signalling is also required for cell migration, axonal and dendritic remodelling and

\section{KARGER}

Fax +4161306 1234

E-Mail karger@karger.ch

www.karger.com
(C) 2012 S. Karger AG, Basel

$1424-862 X / 12 / 0203-0164 \$ 38.00 / 0$

Accessible online at:

www.karger.com/nsg
Joanne Britto

Florey Neuroscience Institutes

University of Melbourne

Parkville, Melbourne, VIC 3010 (Australia)

Tel. +61 390356586 E-Mail joanne.britto@florey.edu.au 
synapse formation [6]; thus, interneurons are key modulators of cortical development and plasticity, in addition to playing a crucial role in shaping the spatiotemporal pattern of neuronal activity.

The last few years have seen an explosion in publications surrounding interneuron development. The diversity of subtypes based on morphological, molecular and electrophysiological differences accentuates the highly specialized role these neurons play in cortical circuits. More recently, we have started to recognize the implications of a dysfunctional GABAergic system in neurodevelopmental disorders, and our efforts go towards addressing the underlying causes of such disturbances in cortical function. As mentioned, the functional heterogeneity of interneurons is key in modulating cortical circuit activity, and a number of recent reviews have discussed how this diversity is associated with cortical function [79]. In this review, we will focus on how interneurons are reliant on intrinsic and extrinsic cues during embryogenesis to establish subtype specification and discuss the impact of these cues on migration and lamination. Furthermore, we will discuss the latest findings of interneuron generation during human cortical development, as knowledge in these mechanisms has long-term implications in defining the aetiology of many neurological and psychiatric conditions.

\section{Cortical Interneuron Origin}

\section{Cortical Interneuron Origin in Rodents}

The concept that pyramidal neurons and interneurons arise from distinct progenitors and display different migratory routes was illustrated by a number of key studies performed in rodents. Initially the use of recombinant retroviral labelling identified clones of cells composed solely of either pyramidal or non-pyramidal cells $[10,11]$ suggesting the existence of separate progenitor pools for these two cell types. Similar studies drew attention to the appearance of tangentially migrating neurons throughout the intermediate zone (IZ), demonstrating the widespread and unorthodox dispersion of these cells within the cortex [12-15]. Although it was not clear at the time that these tangentially migrating neurons originated in the ventral telencephalon, a subsequent series of elegant experiments placing DiI crystals in the ventral telencephalon demonstrated the migration of the cells into the neocortex, a phenomenon that was blocked by an incision made between the dorsal (pallium) and ventral (subpallium) telencephalon [16-19]. It therefore appears that the majority of interneurons are derived from an extracortical source, the ganglionic eminences (GEs) of the ventral telencephalon. There is however evidence to suggest that the dorsal telencephalon can provide a local source in the rodent cortex $[11,20]$, and this may also be the case in human and non-human primates. These aspects of interneuron origin will be discussed in more detail below.

In the mouse, the GEs in the ventral telencephalon appear around embryonic (E) day 11 and can be structurally divided into 3 separate areas, lateral (LGE), medial (MGE) and caudal (CGE), depending on the rostrocaudal and mediolateral position (fig. 1). Utilizing DiI labelling of individual GEs, and in vivo transplantation studies, it was confirmed that almost all cortical interneurons are produced within the MGE and CGE [16, 17, 21-24]. The genetic link for GE involvement in the genesis of interneurons was found by analyzing knockouts of the homeobox-containing transcription factors expressed in this region, namely, Dlx1, Dlx2 and Nkx2.1. Dlx1 and Dlx2 are highly expressed in the GE and the double knockout showed a $70 \%$ reduction in the number of cortical interneurons [19]. In comparison, $\mathrm{Nkx} 2.1$ is expressed solely in the MGE, and the knockout exhibits only a $50 \%$ decrease in interneuron numbers $[25,26]$. More recently, the contribution of interneurons from the CGE has been examined by genetic fate mapping studies indicating that approximately $30 \%$ of cortical interneurons are produced within this area $[27,28]$.

The involvement of the LGE in generating cortical interneurons has been more controversial. Numerous in vitro and in vivo studies have shown that LGE-derived cells fail to migrate to the dorsal cortex [16, 21, 23, 29]; however, others have shown the presence of bromodeoxyuridine-labelled LGE cells in the cortex after heterotopic transplantation [30,31], and tangentially migrating cells were present in the rat cortex following ablation of the MGE [32]. One caveat for these experiments is that the migratory route of MGE- and CGE-derived interneurons is through the LGE. Nonetheless, we cannot completely rule out the LGE as a potential source of cortical neurons. In addition to the GE, a small percentage of cortical interneurons are derived from the embryonic pre-optic area [33]. Genetic lineage tracing using the transcription factor Nkx5.1 and in utero labelling to specifically label the pre-optic area has shown that GABAergic cells from this region also migrate to the cortex and hippocampus.

The studies mentioned above indicate that the majority of interneurons are derived from the MGE and CGE and undergo their final mitosis in these regions prior to migration. However, proliferating interneuron progeni- 
Fig. 1. Schematic representation of migratory routes utilized by interneurons generated in the GEs. a Cortical interneurons born in the MGE and CGE in the ventral telencephalon follow tangential migratory paths into the developing cortex. Once within the cortical wall, cells disperse before entering the cortical plate and reside in a final position. The LGE-derived neurons migrate rostrally and ventrally into the olfactory bulb (OB) and striatum, respectively. b Coronal section (indicated in a) illustrating the major routes of tangential migration through the embryonic telencephalon. Interneurons migrate from the MGE (M) and traverse the LGE (L) whilst avoiding the striatum (Str). Upon entry into the cortical wall, cells migrate in 3 major streams, through the marginal zone at early stages, followed by a second route in the intermediate zone and at later stages through the subplate. c Intracortical migration represented as multidirectional migration within the marginal zone (indicated in b), the inward and outward radial migration from the tangential paths into the cortical plate and the ventricle-directed migration towards the ventricular zone.

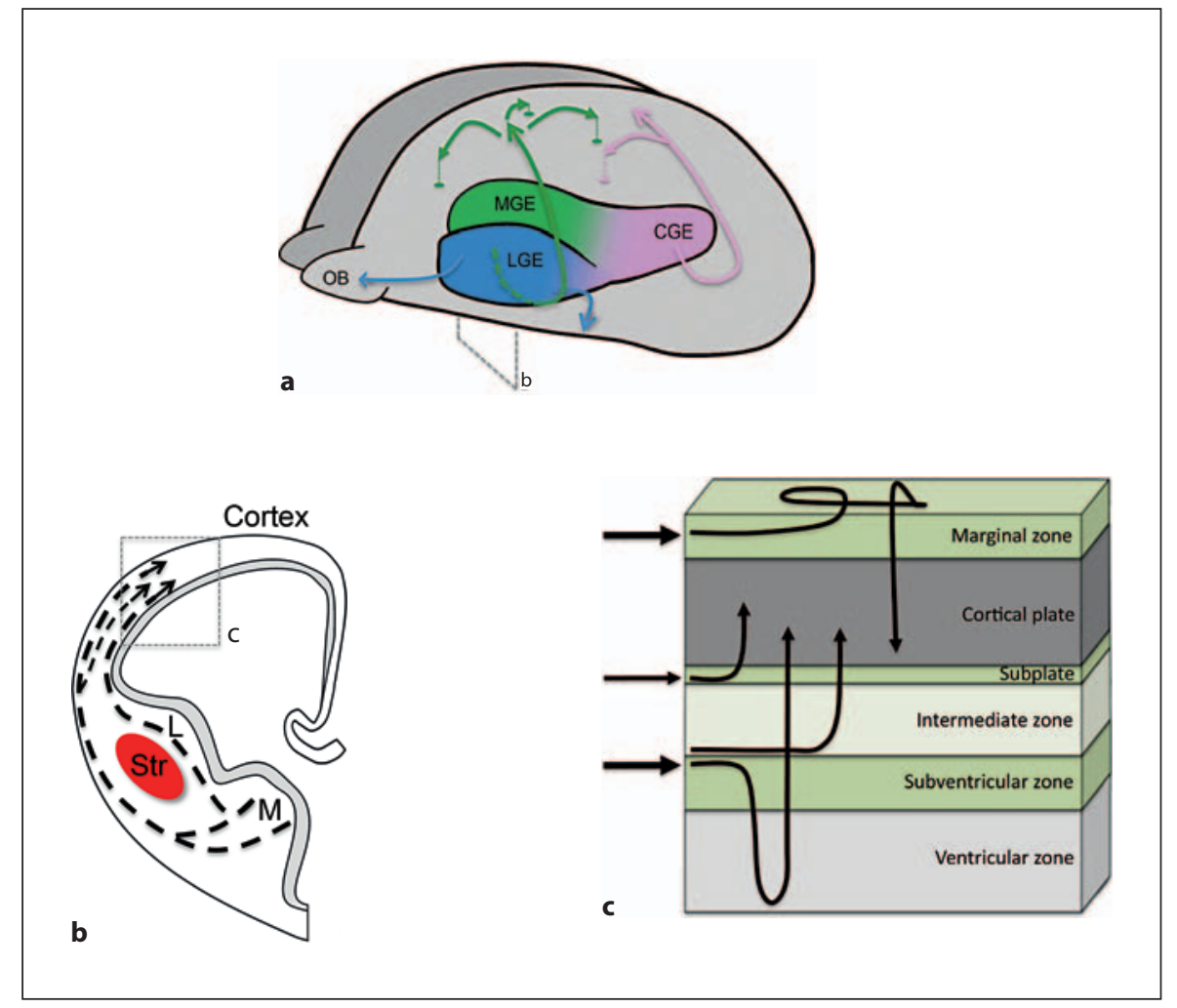

tors have been observed in the postnatal subventricular zone (SVZ) $[11,20,30]$ and the IZ [20] of the cortex. Wu et al. [20] determined that these cells originated in the $\mathrm{GE}$, and maintained the ability to proliferate after reaching the cortex to produce GABAergic daughter cells. A separate study has identified a pool of proliferating GABAergic precursor cells in the postnatal dorsal white matter [34], and although the authors infer the origin of these cells is the LGE/CGE, this is yet to be determined. The requirement for these proliferating GABAergic intermediate progenitors in the cortex remains unknown; however, they may provide a source of inhibitory cells during the late stages of cortical maturation.

\section{Interneuron Origin in Human and Non-Human Primates}

The ability to conduct in vitro and in vivo manipulations, as well as access to transgenic and fate mapping technologies, has made rodents a pertinent model to advance our understanding of cortical development. Nonetheless, if we compare across species, there is an obvious evolutionary increase in the number of both pyramidal neurons and interneurons found in the cortex of higher primates. This is evident by the increase in proportion of
GABAergic neurons from $15 \%$ in rodents to $25 \%$ in the monkey and reaching $34-44 \%$ in certain supragranular layers in the macaque and human [35]. In addition, the existence of interneurons displaying widely varying morphologies in primates indicates that not only are more interneurons required, but newer forms have also been generated. The double bouquet cell originally described in the human cortex by Ramon y Cajal in 1899 and later rediscovered in primates [36] is an archetypal example of this variation. Thus, the question can be raised of whether developmental mechanisms have evolved an additional source of progenitors to proportionately balance the increase in excitatory neurons in a more complex brain.

A hint that this may indeed be the case for human and non-human primates was discovered by Letinic et al. [37] in 2002. This study identified cells in the ventricular zone (VZ) and SVZ of the dorsal telencephalon at mid-gestation, which co-expressed GABA with the GE-associated transcription factors Mash1 (ASCL) and Dlx1/2. In rodents, these transcription factors are associated with interneuron generation [38, 39], and although Mash1 is expressed by progenitors in the GE, it is normally undetectable in postmitotic migratory interneurons. The proliferative capacity of these novel GABA/Mash1-posi- 
tive cells was tested using retroviral labelling in organotypic cultures and a clonal analysis revealed expression of GABA and Dlx2 in the migrating cells and Mash1 expression in both the dividing progenitors and migrating cells [37]. This study highlighted for the first time a local cortical origin of GABAergic interneurons capable of generating the majority of interneurons; however, these results are not without controversy. It is possible that the Mash1positive progenitors are a form of migrating intermediate progenitor/amplifier cell originating in the GE. In addition, it has recently been shown that radial glial cells in the human cortex can directly produce either Tbr2-positive or ASCL-positive cells thereby generating both excitatory and inhibitory lineages, respectively [40]. Interestingly, in this latter study the authors could not distinguish the distinct precursors for inhibitory neurons as all ASCL-positive cells co-expressed Sox2 (a neural stem cell/progenitor cell marker) and/or Tbr2. In rodents, Mash1 has also been associated with the generation of oligodendrocytes [41] and the relevance of this in human development is not yet known.

A study in the monkey cortex has revealed a temporal perspective on interneuron generation and migration. Not only was it confirmed that GABAergic cells were generated in the VZ/SVZ of the dorsal telencephalon (Mash1positive) and GE (Mash1-negative), these results suggested also that the site of origin dictated the birthdate of interneurons, as well as their laminar positioning [42]. To summarize, the GE-derived interneurons arise during early gestation and are located in the marginal zone (MZ) and subplate (SP), whereas at later stages of gestation cortically derived interneurons are generated. The lack of time lapse analysis precludes any definitive confirmation of the migratory routes adopted from the two sites of origin; nonetheless, these data illustrate an evolutionary conservation of Mash1-positive progenitors in the dorsal telencephalon. Subsequent studies, driven largely by Zecevic and colleagues, have broadened our understanding of interneuron biology during human cortical development [43-46]. By analysing the expression profiles of GE-associated transcription factors (Nkx2.1, Dlx1, Dlx2, Lhx6 and Mash1) combined with an interneuron subtype marker (calcium-binding protein, calretinin) and a proliferation marker (Ki67), the authors have corroborated the presence of a progenitor population within the VZ/ SVZ.

Ultimately, it would be ideal to identify the subtype fate of interneurons generated in the dorsal telencephalon; however, limitations of studying human tissue prevent this. Abnormalities in cortical interneuron develop-

Migration and Lamination of Cortical Interneurons ment have been linked to a number of human disorders (outlined in the section 'Neurodevelopmental disorders and interneuron development') and a recent study investigating fetal or infant cases of holoprosencephaly with severe ventral forebrain hypoplasia [47] may shed light on interneuron progenitor fates. In these cortices, a substantial reduction was observed in interneurons positive for the markers nitric oxide synthase 1 , neuropeptide $\mathrm{Y}$ and somatostatin (SST); in contrast, calretinin-positive cells were still present. Interestingly, the interneuron subtypes that showed the greatest reduction are derived from the ventrally located GE, and the presence of the calretininpositive interneurons is indicative of an additional progenitor population outside the ventral telencephalon. The significance of these subtypes, and connection to the site of origin, will become apparent in the following section, where we discuss in detail the generation of interneuron diversity.

\section{Interneuron Diversity}

The first section of this review outlined the regions within the telencephalon that generate interneurons, but the next phase of interneuron development is fate determination and cortical positioning. Interneurons are a heterogeneous population and the task of classifying them into subpopulations is a daunting one. Over the past few years various attempts have been made and more recently a consortium of scientists specializing in anatomy, physiology and development convened to create a unifying nomenclature of GABAergic interneurons in the cortex, the Petilla terminology (Petilla Interneuron Nomenclature Group) [48]. We will briefly describe the main approaches used for interneuron classification below; however, a detailed description of interneuron subtypes is beyond the scope of this review and has recently been provided elsewhere $[8,9,48-50]$.

Subtype classifications are generally based on 3 major criteria: (1) the molecular profile, (2) morphology and (3) electrophysiology of the interneuron. The first of these rely on the expression of molecular markers and is probably the simplest and most commonly used. These include: the calcium-binding proteins parvalbumin (PV), calbindin (CB) and calretinin (CR); certain neuropeptides, such as SST, vaso-active intestinal peptide (VIP), neuropeptide Y, cholecystokinin and corticotropin-releasing factor [51-53]; potassium channels such as Kv3.1 and $\mathrm{Kv} 3.2$ [54, 55]; the secreted glycoprotein reelin [27]; nitric oxide synthase [53], and the serotonin receptor 
5-hydroxytryptamine 3A (5HT3aR) [56, 57]. Based on their expression patterns, recent studies have shown that PV, SST and 5HT3aR are exclusively expressed by 3 distinct subpopulations and when combined account for the majority of GABAergic cells [50, 56, 58]. Further subdivisions of interneurons arise from the combinatorial expression of the molecular markers listed above $[27,53,58]$. The second major criterion, cell morphology, accounts for differences in soma size and shape, dendritic and axonal arborizations and location of postsynaptic connections. Finally, electrophysiology depicts the firing properties that characterize interneuron activity within the cortical circuitry $[7,8]$. It is now widely believed that each of the above criteria should be used when identifying or describing specific interneuron subtypes. Interestingly, it was noted at the end of the Petilla meeting that these segregations are primarily for the benefit of investigators trying to categorize a diverse system governed by its role in neuromodulation. Regardless, these classifications have recognized the large diversity of interneurons that exists across various regions of the cortex $[8,27,51,58-63]$.

\section{The Generation of Interneuron Diversity}

To comprehend how such a high level of diversity is created, we need to adopt a developmental perspective and follow the life span of an interneuron from birth to maturation. If we do this, there are 3 key phases when the identity of an interneuron can be influenced: (1) specification at birth, (2) exposure to signals during migration and final positioning in the cortical plate (CP) and (3) synaptic maturation and connectivity that ultimately defines the neuromodulatory function of an interneuron. It becomes evident that these are either an intrinsic property of the interneuron or the influence of extrinsic factors from the cortical surrounds. Nonetheless, there is evidence to suggest that all 3 play a role in determining the fate of an interneuron. We will focus here on the rodent model, as the wealth of data allows us to present a rationale for each phase of development.

The first event would state that interneurons are specified at the time of birth and therefore subtype specification is largely defined within the GE. The obvious molecular candidates would be transcription factors (table 1), and Rubenstein and colleagues have been influential in discovering an array of factors that define the GE as a distinct developmental domain [39, 64-69]. Dlx1 and Dlx2 are expressed throughout the SVZ of the GE and confer an interneuron fate upon the newly born cells. Distinct subtypes of interneurons are spatially and/ or temporally segregated within the pool of Dlx-positive progenitors, and transplantation studies $[23,70]$, genetic fate mapping [28, 56, 71] and cell culture analysis [72] have provided a broad map of subtype origin. More specifically, MGE-derived interneurons are mainly PV-positive fast-spiking basket cells and SST-positive intrinsic bursting Martinotti cells, while all CGE-derived cells are positive for $5 \mathrm{HT} 3 \mathrm{aR}$, exhibit a range of firing potentials and morphologies, and are further subdivided by their expression of VIP, CR and neuropeptide Y $[7,8]$.

A spatial bias also exists within the MGE itself as PVpositive cells arise primarily from the ventral MGE and SST-positive cells from the dorsal MGE [73, 74]. Interestingly, it appears that a gradient of sonic hedgehog activity is driving this spatial bias [69,75-77]. If these findings suggest parity with the generation of interneuron diversity in the spinal cord [78], then domain-creating transcription factors would need to be present in the MGE. Indeed, central to interneuron specification is an array of transcription factors (Nkx2.1, Nkx 6.2, Lhx6, CoupTFI, Cux 1, 2, Sox6 and Dlx5/6) [29, 65, 79-87]; however, expression patterns do not create clearly defined boundaries that are subtype specific. More recently, attempts were made to delineate progenitor domains by the combinatorial expression of transcription factors [39, 68]; once again, the borders are not sharply defined, and multiple subtypes could be produced within the progenitor regions.

We have described specification occurring in a spatial manner; however, increasing evidence suggests that a temporal regulation also exists $[27,60,86]$. Interneuron genesis in mice takes place between $\mathrm{E} 9$ and $\mathrm{E} 16$, and the peak production from the MGE occurs around E12-E13. In contrast, the initiation and peak production of interneurons from the CGE is around E12 and E15-E16, respectively $[27,60]$. This temporal pattern is reflected by the subtypes that are generated, for example, most SSTpositive Martinotti cells are predominantly born at E9, SST- and CR-double-positive cells at E12 and most VIPpositive cells at E15 $[60,86]$. In comparison, although PVpositive cells are produced throughout the entire genesis period, PV-positive chandelier cells are produced at E15 [74] implying specific temporal delineation in subtype generation. This developmental scenario is analogous to the generation of pyramidal neurons, where the temporal expression of transcription factors (Brn1/2, Svet1, Cux1, Cux2) controls the sequential production of deep versus superficial cortical neurons [88]. Furthermore, as described above, the temporal profile of interneuron subtype generation may exist in humans, albeit from different cortical sources. 
Table 1. Genes involved in interneuron development

\begin{tabular}{|c|c|c|}
\hline $\begin{array}{l}\text { Role in interneuron } \\
\text { development }\end{array}$ & Transcription factors & Ligand-receptor signalling \\
\hline Proliferation & $\beta$-Catenin (Wnt-mediated) [230] & Cyclin $\mathrm{D}_{2}[231]$ \\
\hline Differentiation & $\begin{array}{l}\text { Cux1/Cux2 }[82] \\
\text { Dlx1, 2, 5, } 6[39,64,65,80,85] \\
\text { Lhx6, } 8[69,162] \\
\text { Mash1 }[37-39]\end{array}$ & $\begin{array}{l}\text { GDNF/GFR } \alpha_{1}[126] \\
\text { Ryk }[232] \\
\text { Shh }[69,75,77]\end{array}$ \\
\hline $\begin{array}{l}\text { Subtype specification } \\
\text { MGE derived }\end{array}$ & $\begin{array}{l}\text { Lhx6 }[69,162] \\
\text { Nkx2.1 }[72,79,162] \\
\text { Nkx6.2 [86] } \\
\text { Sox6 }[84]\end{array}$ & $\begin{array}{l}\text { BMP/BMPR1 [89] } \\
\text { BDNF/TrkB }[31,90,91] \\
\text { Kir2.1 [96] }\end{array}$ \\
\hline CGE derived & Coup-TFI [81] & \\
\hline $\begin{array}{l}\text { Migration } \\
\text { Tangential }\end{array}$ & $\begin{array}{l}\text { Arx }[157,158,218] \\
\text { Coup-TFII }[29] \\
\text { Dcx }[106,107,218] \\
\text { Dlx1, Dlx2 }[19,160,161] \\
\text { Lhx6 }[87,156,159]\end{array}$ & $\begin{array}{l}\text { BDNF/TrkB [31, 125] } \\
\text { CXCL12/CXCR4, } 7[144,145,183-186,188] \\
\text { GDNF/GFR } \alpha_{1}[126] \\
\text { HGF/SF [115] } \\
\text { Netrin } 1[189] \\
\text { NRG1/ErbB4 }[99,146,149] \\
\text { p35 [108] }\end{array}$ \\
\hline $\begin{array}{l}\text { Guidance through } \\
\text { ventral telencephalon }\end{array}$ & & $\begin{array}{l}\text { Eph/ephrin }[141,142] \\
\text { Robo }[136,137,140] \\
\text { Sema }[129,130,140]\end{array}$ \\
\hline Regional distribution & & GDNF/GFR $\alpha_{1}[128]$ \\
\hline Switch to radial & Sox6 $[83,84]$ & $\begin{array}{l}\text { Connexin } 43 \text { [182] } \\
\text { Netrin } 1 \text { [189] }\end{array}$ \\
\hline $\begin{array}{l}\text { Lamination and } \\
\text { termination }\end{array}$ & $\begin{array}{l}\text { Sox6 [83] } \\
\text { Fezf2 }[204]\end{array}$ & $\begin{array}{l}\text { BDNF/TrkB [125] } \\
\text { CXCL12/CXCR4/CXCR7 }[144,184,186,187] \\
\text { KCC2 [207] } \\
\text { Kir2.1 [96] } \\
\text { p35 [108] } \\
\text { Reelin }[180,200,202,203]\end{array}$ \\
\hline
\end{tabular}

Overall, there is clear evidence to suggest that both the progenitor location and time of birth are two highly influential factors in determining the fate of an interneuron. Interestingly, many characteristics used to define an interneuron are not evident until late postnatal ages and even adulthood. Synaptic maturation of interneurons is a protracted process strongly regulated by experiencedriven neural activity (this can span up to the first two decades in humans). This leaves abundant time for interneuron identity to be modified during migration into the $\mathrm{CP}$ and integration into functional circuits, leading us to the second and third phases of interneuron specification where extrinsic factors can influence interneuron iden- tity (table 1). It has been shown that certain dorsalizing signals, such as BMP4, can increase the number of PVpositive cells, with a concomitant decrease in SST-positive cell number [89]. Brain-derived neurotrophic factor (BDNF) signalling also differentially alters interneuron subpopulations both in vitro and in vivo [31, 90, 91]. In addition, cell morphology is modified by environmental signals, such as BDNF, the soluble form of neural cell adhesion molecule and even GABA, which all regulate axonal and dendritic branching as well as synaptogenesis [92-95]. Altered neuronal excitability may also play a role in interneuron specification, as demonstrated recently in an elegant study by De Marco Garcia et al. [96]. This 
study found that altering the electrical activity of CGEderived interneurons, by overexpressing the potassium channel Kir2.1, caused a pronounced change in the morphology of CR- and reelin-positive cells. In contrast, VIPpositive neurons were unaffected. Interestingly, the alteration in cell morphology only arose when neuronal activity was modified after postnatal day 5 , a time well beyond genesis in the GE.

The extrinsic activation of intracellular signalling pathways is crucial in modulating neuronal excitability, and it is hardly surprising that molecular changes arise during synaptogenesis. For this reason many believed that interneurons were 'naïve' until these later stages of development and this may not be far from the truth. Taken together, the studies described above indicate that interneurons within the $\mathrm{CP}$ are not necessarily naïve, but are restricted in fate by transcription factor expression at birth and are further refined following exposure to the cortical environment and integration into microcortical networks. It is therefore becoming increasingly apparent that the combination of all 3 phases in interneuron development contributes to generating interneuron heterogeneity in the adult cortex.

\section{Tangential and Radial Migratory Routes}

Neuronal migration constitutes a fundamental process during cortical development, and through a sequence of highly orchestrated events the characteristic laminated structure of the adult cortex is formed. The ability of neurons to navigate the cellular milieu while integrating multiple guidance cues is a marvel in itself, and great efforts are made to comprehend the molecular basis of this process. The cellular events during corticogenesis provide an elegant model for investigating such processes as the two neuronal populations have adopted distinct migratory behaviours to eventually reside in a common terminus. Pyramidal neurons generated locally in the neuro-epithelium migrate radially from progenitors in the VZ/SVZ towards the CP, whilst interneurons generated in a subcortical progenitor zone embark on tangential migration (parallel to the ventricular surface) before entering the CP. Regardless of subtype or site of origin, all interneurons must migrate vast distances to reach a final destination.

There are 3 major routes of migration observed for interneurons during corticogenesis; the first is along well-defined tangential paths from the GE towards the corticostriatal junction and into the cortical wall, the second encompasses multidirectional migration within these migratory paths and the third involves a shift towards a radial trajectory so as to enter the CP (fig. 1). These last 2 routes will be referred to as 'intracortical' migration, indicating the phase of interneuron movement into the laminated $\mathrm{CP}$ generated by pyramidal neurons. Although we focus this review on cortical interneurons, these migratory streams are also utilized by hippocampal interneurons, which traverse the cortex before entering the hippocampal primordium in a stagedependent manner [17, 19, 23, 97]. Various guidance molecules, substrates and intrinsic programming signals are required to direct the migrating interneurons to their correct laminar position, and these will be discussed in the following sections. First, however, we will describe the dynamic cellular mechanisms of interneuron movement, as this is instrumental for guidance-directed migration.

\section{The Branching Dynamics of Migrating Interneurons}

Unlike pyramidal cells, which are associated with radial glial fibres and migrate primarily in a straight trajectory, migrating interneurons navigate without any obvious physical support and change direction frequently. To do so, and similar to growing axons, interneurons use their leading process (neurite) as a compass, having a growth-cone-like structure at the distal end. Whilst axons manoeuvre the growth cone towards or away from chemotactic cues, interneurons continuously produce multiple branches from the leading neurite, subsequently selecting a single branch oriented in the direction of the attractive cue $[98,99]$ (fig. 2). This migratory behaviour is disparate to the chain migration of olfactory interneurons in the rostral migratory stream [100], but turns out to be required for directional guidance. The individual searching behaviour of cortical interneurons is evidenced by vigorous and dynamic neurite branching, and intermittent leaps made by the nucleus to advance the cell (nucleokinesis). This saltatory nuclear translocation appears uncorrelated to the dynamic branching of neurites at the leading edge of the cell $[98,101]$. A recent study examining the relationship between nucleus movement and the temporal extension and retraction of neurites has highlighted independence between these two cellular mechanisms, that is, once the choice of a leading neurite is made, the nucleus moves despite the degree of branching in the neuritic arbour [102]. This is not to say that neuritic branching is decoupled from nucleokinesis, as signalling unequivocally occurs from the growth cone to the cell, but rather these cellular dynamics represent a very effi- 
cient manner for searching and moving through an unknown environment.

The process of nucleokinesis occurs in two phases. First, cytoplasmic organelles (i.e. the Golgi/centrosome) move forward and separate from the nucleus. This is followed by the splitting of the centrosome and nuclear translocation towards the organelles. Interestingly, close observation of this nuclear movement revealed that when an interneuron is migrating in a relatively constant direction, the nucleus tends to alternate between left and right leading neurite branches [99]. Nuclear movement occurs through actomyosin-dependent pushing forces from the rear of the cell and microtubule-associated pulling forces ahead of the nucleus $[98,103,104]$. One of the key steps in interneuron migration is the stabilization of the microtubules in the leading neurite. Disruption in microtubule dynamics, for example through the deletion of microtubule-associated proteins, such as lissencephaly 1 (Lis1) [105] and doublecortin (Dcx) [106, 107], or upstream regulators like p35/Cdk5 [108, 109], leads to abnormal neurite branching and causes the misguided migration of the cells.

\section{Tangential Interneuron Migration}

Tracing, fate-mapping and loss of function analyses have shown 3 major migratory paths that interneurons follow from their origins in the ventral telencephalon to the cortex [110-112]. Specifically, an early cohort (E12 in the mouse) first reaches the cortex and migrates at the level of the preplate. A second and more prominent cohort migrates predominantly through the IZ. At the later stages of corticogenesis (E14-E15) and after the formation of the CP, 3 distinct tangential migratory streams are evident in the developing cortex, located in the MZ, SP and lower IZ/SVZ (fig. 1) [17, 30, 112]. Thus, intricate molecular mechanisms including an array of motogenic factors, chemotactic guidance cues, transcription factors and neurotransmitters are employed by interneurons throughout tangential migration (table 1$)[113,114]$ and we will discuss each in turn.

\section{Motogenic Cues}

A number of soluble factors have been proposed to play a role in cortical interneuron migration by acting as 'promovement' or motogenic factors. For instance, hepatocyte growth factor/scatter factor enhances the migration of cells away from the ventral telencephalon, and loss in its activity causes undirected migration of interneurons within the GE leading to a reduction in the number of interneurons in the cortex [115]. Members of the neu-

Migration and Lamination of Cortical Interneurons rotrophin family have also been proposed as motogenic factors in the migration of interneurons. Neurotrophins are widely expressed in the developing cortex [116-119] and interneurons express the tyrosine kinase receptors TrkB and TrkC, the cognate receptors for neurotrophins $[120,121]$. Both BDNF and neurotrophin 4 stimulate interneuron migration, and analysis of the TrkB-null cortex revealed a significant reduction in the number of CBpositive interneurons [31]. Recently, the calcium-dependent activator protein for secretion 2 has been shown to promote BDNF secretion, and analysis of null mice for this protein revealed a decreased number of GABAergic neurons and their synapses in the hippocampus [122], thus confirming a role for BDNF in interneuron migration. However, the role of BDNF in cortical interneuron development is not without debate. Other studies have suggested that disruption of BDNF signalling leads to downregulation of $\mathrm{CB}$ and other neuropeptides expressed in interneurons $[91,123,124]$. This would cast some doubt as to whether the reduction of interneuron numbers in the absence of TrkB reflects an actual defect in migration or simply a reduction of cell markers. Additionally, changes to the endogenous levels of BDNF may impair cortical development, and the effects on interneuron positioning may be a secondary phenotype. This is indeed the case when analysing the nestin-BDNF transgenic mice, where exogenous levels of BDNF not only led to an inappropriate segregation of Cajal-Retzius cells and interneurons in the $\mathrm{MZ}$, but altered cortical organization and impaired final radial migration of interneurons [125].

The neurotrophin glial cell line-derived neurotrophic factor is highly expressed in interneuron migratory pathways in the cortex [126]. Members of the glial derived neurotrophic factor ligand family signal by binding to glycosylphosphatidylinositol-anchored receptors, GFR $\alpha_{1-4}$, in collaboration with the RET receptor tyrosine kinase [127]. Interneurons in GFR $\alpha_{1}$-null mutants were found misrouted in the MGE and significantly reduced in the cortex. A follow-up study, using the homozygous GFR $\alpha_{1}$-null rescued by expression of Gfral gene from the Ret locus, revealed regionalized loss of PV-positive interneurons [128]. This presents a scenario where guidance molecules may guide certain subtypes of interneurons to discrete regions of the cortex.

\section{Chemotactic Molecules}

Once generated in the MGE, postmitotic interneurons journey towards the cortex by first traversing the developing LGE (striatum primordium) en route to the corti 
costriatal junction. Guidance cues play a key role in directing interneuron migration in this area. Most will be familiar with chemo-attractive and chemorepulsive cues required for axon guidance; interestingly, these same families of proteins are involved in the guidance-directed migration of interneurons. To avoid entering the striatum, migrating interneurons express neuropilins (Nrp1 and Nrp2) and plexin coreceptors that respond to the chemorepulsive ligands semaphorin (Sema) $3 \mathrm{~A}$ and $3 \mathrm{~F}$ emanating from the striatal mantle [129]. In addition, the proteoglycan chondroitin-4-sulphate is expressed in the striatal mantle [130], which, in conjunction with the semaphorins, creates an exclusion zone for migrating interneurons to channel into adjacent paths and thus define the formation of migratory routes into the cortex. The Sema proteins are also active in the neocortex and act to direct interneuron migration in the tangential streams, preventing them from entering the $\mathrm{CP}$ [131].

The chemorepulsive ligand Slit1 is strongly expressed throughout the VZ and SVZ of the GE as well as the preoptic area [132-135] and the corresponding receptor roundabout (Robo) is expressed by interneurons. The complementary expression patterns of Slit-Robo suggest Slit proteins might repel interneurons from the GE to the cerebral cortex [136-139]. Surprisingly, no defects in the tangential migration or differences in the number or distribution of interneurons (GABA-, Lhx6- or Dlx2-positive) were detected in the cortices of Slit1/Slit2 double mutant [111]. Nonetheless, the analysis of two different Robol-deficient transgenic models have shown a significant influx of CB-positive cells within the developing striatum, as well as an increased number of interneurons within the developing and adult cortex [136, 137]. This suggests that Robol-null effects could be Slit independent, and this has been confirmed with the recent discovery that Robol modulates semaphorin-neuropilin/plexin signalling to steer interneurons around the striatum and into the cortex [140].

Keeping with the classic collection of guidance cues, the membrane-bound ephrin and Eph receptor tyrosine kinases (Eph) also play a role in interneuron migration. Experimental in vitro and in vivo evidence has revealed the involvement of ephrins in directing migration and enhancing the motility of neurons $[141,142]$. Ephrin A5 and its receptor EphA4 are complementarily expressed in the VZ and SVZ of the GE, respectively, and CB-positive cells isolated from the MGE express the EphA4 receptor [141]. In vitro stripe assays have demonstrated that both ephrin A5 and ephrin A3 are potent chemorepellents for MGE-derived neurons. Downregulation of the EphA4 re- ceptor, using siRNA, reduced the repulsive effect of ephrin A3 implicating EphA4 in mediating in part the repulsive effects of ephrin A3 [142]. Together, these results suggest that Eph/ephrin signalling acts as a repulsive cue that restricts cortical interneuron migration from inappropriate regions and are contributing factors in defining the migratory route of cortical interneurons.

Even though inhibitory cues are necessary to guide migration, interneurons are also directed towards the cortex in response to attractive cues. One such candidate is the chemokine CXCL12 (stromal cell-derived factor, SDF1) which signals through the receptors CXCR4 and CXCR7. During early corticogenesis (up to E14.5), CXCL12 expression is high in the MZ and SVZ, whereas at later stages, expression remains high in the MZ but is dramatically reduced in the SVZ [143]. The receptors CXCR4 and CXCR7 are expressed on tangentially migrating interneurons [144]. It has been shown that CXCL12 attracts interneurons from the MGE, guiding them to the tangential migratory streams and maintaining them here until the appropriate radial migratory cue is received (see radial migration below) [145].

A second candidate, the neuregulin 1 (NRG1) family of proteins, is essential for interneurons to leave the MGE, travel through the LGE permissive corridor, circumvent the corticostriatal notch and enter into the cortical wall [146]. There are several lines of evidence to suggest a role for NRG1 signalling during interneuron migration. Flames et al. [146] found that different isoforms of NRG1 play distinct roles along the migratory path. The membrane-bound isoform of NRG1 (type III) is found highly expressed by so-called corridor cells present in the SVZ but not the VZ of the LGE. Together with the inhibitory action of semaphorins emanating from the striatum, a permissive corridor is created along the SVZ for interneurons to traverse the LGE. To cross the corticostriatal notch, interneurons require the secreted isoforms of NRG1 (types I and II), which are expressed in the neocortex and act as a long-range chemo-attractant for migrating interneurons. The immediate action of interneurons exposed to an exogenous source of secreted NRG1 is to alter the direction of migration by the extension of a new leading neurite in the direction of the source (fig. 2) [99]. In the long term, when cortical NRG1 expression is reduced, there is a concomitant accumulation of ErbB4positive interneurons at the corticostriatal junction [147] and the complete loss of NRG1 in the forebrain leaves interneurons incapable of leaving the MGE [146].

The expression of ErbB4 (NRG1 receptor) in cortical interneurons $[148,149]$ is conserved across a number of 
species including rodents, macaques and humans [150], and NRG1 has reproducibly emerged as being a candidate susceptibility gene for schizophrenia [151-155]. A dysfunctional GABAergic system is an underlying element in schizophrenia, and the link between NRG1 and early interneuron migration suggests a developmental aetiology. The importance of this will be discussed when we review neurodevelopmental disorders associated with interneuron migration.

\section{Transcription Factors}

The idea that transcription factors are involved in migration is quite removed from the classic role of enhancing or repressing genes for cell fate determination; however, this can be achieved through the regulation of guidance cue receptors. For example, loss of function studies for Lhx6 lim-homeobox transcription factor $[87,156]$ and Arx homeodomain transcription factor $[157,158]$ in mouse brain slices have shown impeded tangential migration of interneurons into the cortex. Recently Lhx6 has been shown to mediate its effects through promoting expression of receptors involved in interneuron migration (ErbB4, CXCR4 and CXCR7), and through promoting the expression of transcription factors either known (Arx) or implicated (bMaf, Cux2 and NPAS1) in controlling interneuron development [159].

The homeobox genes Dlx1/2 are essential not only for the migration of interneuron precursors but also for their maturation in the cortex $[19,160]$. Recent evidence suggests that Dlx1 and Dlx2 regulation of interneuron migration depends on its ability to restrain neurite outgrowth. These effects appear to be mediated by Dlx $1 / 2$ repression of several genes involved in regulating cytoskeletal dynamics including PAK3 and MAP2 [160]. PAK3 expression is low in migrating interneurons and upregulated upon arrival at the cortex when it is required for neurite outgrowth. The repressive action of $\mathrm{Dlx} 1 / 2$ on PAK3 in MGE-derived interneurons is critical in promoting tangential migration, and this was elegantly demonstrated by reducing the aberrant PAK3 and MAP2 expression in the $\mathrm{Dlx} 1 / 2$ double mutant to substantially rescue the tangential migration defects [160]. In a parallel study, Le et al. [161] found that Dlx1/2 mediated the repression of the receptor Nrp2 and therefore may facilitate migration through regulating the response to class 3 semaphorins.

The homeodomain factor Nkx2.1 is specifically expressed in MGE interneuron progenitors and required for the specification of cortical interneuron subtypes [79, 162]. The expression of Nkx2.1, however, is downregu-

Migration and Lamination of Cortical Interneurons lated in interneurons entering the migratory route in the cortex [163], and this downregulation is in fact an active step taken by cortical interneurons to coordinate their programmes of differentiation and migration [163]. Nkx2.1 was also shown to repress Nrp levels. The ectopic expression of $\mathrm{Nkx} 2.1$ in migrating MGE-derived cells rendered them insensitive to Sema3A/Sema3F chemorepulsion, likely due to a reduction in the expression of Nrp1 and Nrp2 [163]. Collectively, the above examples exemplify the dynamic temporal expression of transcription factors and how this function is required not only for interneuron differentiation, but also for the coordination of interneuron migration.

\section{Neurotransmitters}

Neurotransmitters are recognized more for a central role in synaptic transmission and the functionality of cortical networks; however, increasing evidence suggests a role in regulating interneuron migration. An assortment of electrophysiological and pharmacological studies have shown that neurotransmitters play a combinatorial role in guiding interneurons across the corticostriatal junction and maintaining the migratory distribution within the cortical wall. To outline the expression profile of neurotransmitters and their corresponding receptors during migration, GABA is present along the main migratory routes and interneurons express $\mathrm{GABA}_{\mathrm{A}}$ and $\mathrm{GABA}_{B}$ receptors [164-166]. Dopamine is expressed in the MGE and its corresponding $\mathrm{D}_{1}$ and $\mathrm{D}_{2}$ receptors are expressed on interneurons $[167,168]$ and functional glutamate receptors are present on interneurons migrating in the IZ [169-171]. This story becomes interesting when we examine the phenotypes of the individual receptor knockouts or use of pharmacological blockers throughout the migratory phase.

During corticogenesis, $\mathrm{GABA}_{\mathrm{A}}$ receptors bind GABA with higher affinity than mature neurons [172] and the ambient levels of GABA along the migratory route elicit a depolarizing response to modulate migration [164]. Blocking this activity by the treatment of bicucilline or neutralizing GABA antibodies leads to an accumulation of interneurons at the corticostriatal junction; conversely, the addition of GABA enhanced migration into the cortical wall [164]. Several studies have demonstrated the variation in $\mathrm{GABA}_{\mathrm{A}}$ receptor subunit expression during development $[76,173]$ and a recent profiling of single-cells combined with electrophysiological recordings has noted that interneurons migrating in the cortex have a higher affinity, and increased responsiveness to GABA, compared to interneurons in the MGE [166]. This regional 
Fig. 2. Interneuron morphology and branching dynamics during migration. Interneurons respond to guidance cues by changing the direction and length of a leading process. Each neuritic process has a growth-cone-like structure at the distal end that is used to scan the environment and determine the direction of movement. Neurites will extend towards chemo-attractants (+), i.e. CXCL12 and neuregulin, and are repelled by chemorepellents (-), i.e. semaphorin and ephrin. Once a leading process is determined, the soma moves to the branch point of the leading neurite, and other cell processes retract. New branches are formed and through a cycle of neurite extension and retraction the interneuron can change the direction of migration.

Fig. 3. Factors affecting interneuron lamination in the rodent cortex. a During embryonic development, interneurons are maintained in the tangential migratory streams in the MZ, SP and SVZ by various cues, only transiently entering the CP. Disruption in CXCR4 signalling results in the premature invasion of interneurons into the $\mathrm{CP}$, subsequently disrupting lamination. $\mathbf{b}$ By the completion of interneuron lamination in the adult, MGE-derived PVand SST-positive interneurons predominantly occupy deeper cortical layers (layers IV-VI), while CGE-derived 5HT3aRpositive cells primarily occupy more superficial layers (layers II/III). Disruption to reelin signalling (reeler mutant) reverses the lamination of these cells. Similarly, a disruption in p35 signalling reverses interneuron lamination with a partial loss in PV- and SST-positive cells. Alterations in $\mathrm{GFR} \alpha_{1}$ signalling also cause the regionalized loss of a subpopulation of PVpositive cells. In comparison, ablation of Fezf2 expression causes a shift in PV-and SST-positive interneurons to more superficial layers.
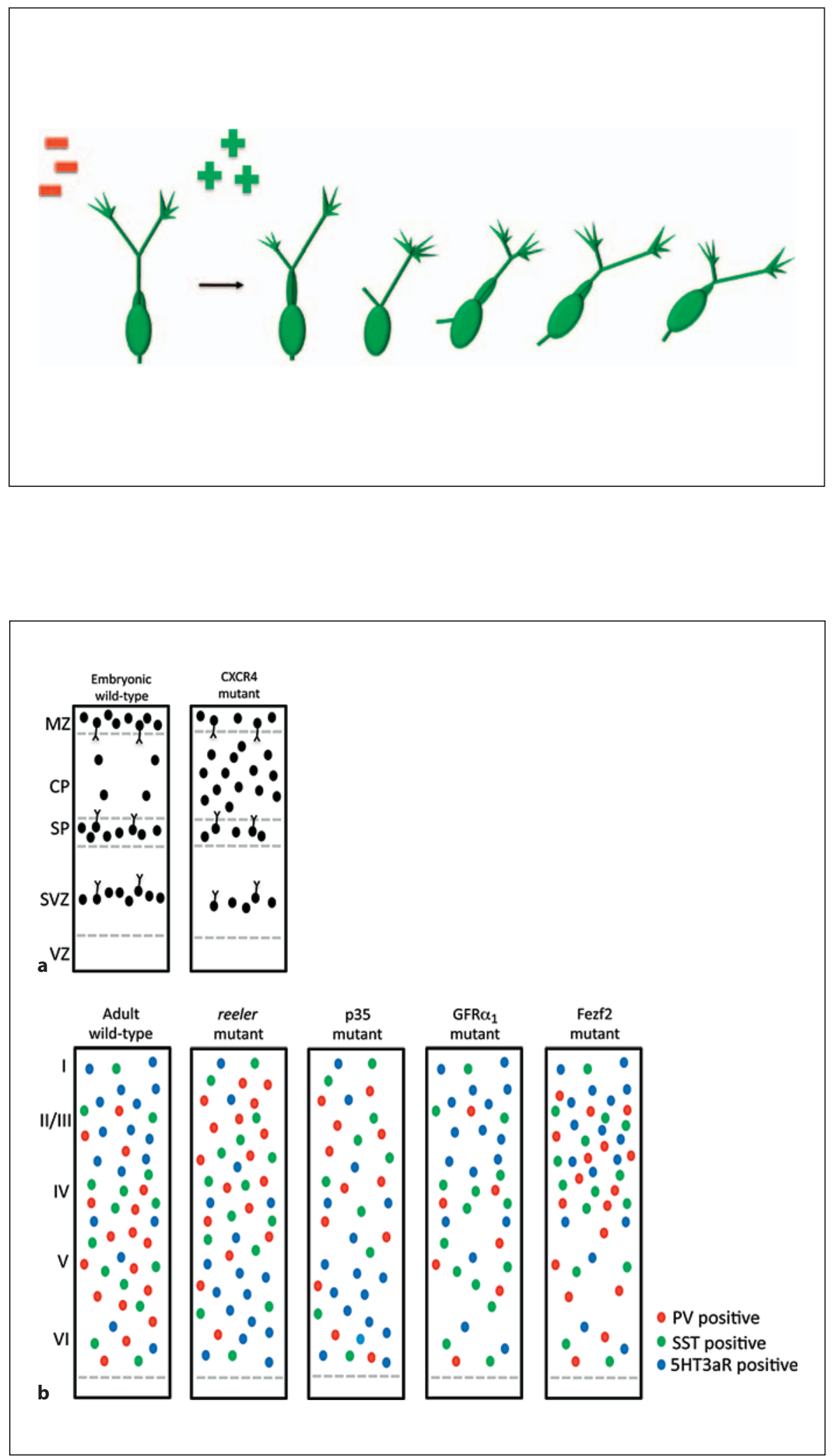
selective response to GABA was accompanied with alterations in GABA isoforms present on individual neurons and highlights the maturation of interneurons during the migration process. In addition, selective antagonists to the $\mathrm{GABA}_{B}$ receptors result in an accumulation of interneurons in the VZ/SVZ and a reduction in the migration through the $\mathrm{CP}$ and $\mathrm{MZ}$ [165]. It is unclear whether this change in distribution arises initially from misguided routes in the MGE or variation in radial migration within the cortex, time lapse analysis would be beneficial in elucidating this query.

The expression of the dopamine receptors $\mathrm{D}_{1}$ and $\mathrm{D}_{2}$ on interneurons and the MGE being a source of dopamine suggests a role for this neurotransmitter in migration [168], and indeed this is the case. Intriguingly, the individual activation of $\mathrm{D}_{1}$ or $\mathrm{D}_{2}$ receptors produce opposing effects [167]. Pharmacological blocking of $\mathrm{D}_{1}$ receptor activity, which induces concomitant activation of the $\mathrm{D}_{2}$ receptor, decreases the migration of interneurons into the cortex and implies that $\mathrm{D}_{1}$ receptor activation promotes migration whereas $\mathrm{D}_{2}$ receptor activation is inhibitory. This was confirmed further by analysis of the individual receptor knockouts. Although there was no change in the total number of interneurons in the CP/ $\mathrm{MZ}$, the $\mathrm{D}_{1}$ receptor knockout showed a significant decrease in the number of interneurons in the IZ/SVZ, whilst the $\mathrm{D}_{2}$ receptor knockout exhibited an increase in interneurons in this domain [167]. A recent study investigating the downstream molecular mechanisms of $\mathrm{D}_{2}$ receptor activation in zebrafish [174] has illustrated the conserved nature of this signalling pathway for interneuron development and the importance of maintaining neurotransmitter homeostasis to promote the correct migration and positioning of cortical interneurons.

As described above, a vast array of motogenic and chemotactic cues, transcription factors and neurotransmitters instruct and guide the tangential migration of the interneurons from the ventral telencephalon into the neocortex. Some of these factors also influence the intracortical migration and lamination of the interneurons. We will discuss these processes and the molecules involved below.

\section{Intracortical Migration of Interneurons}

Once interneurons arrive in the cortex, different modes of migration are employed. We refer to this as intracortical migration. These migratory behaviours include: (1) the multidirectional migration within tangential routes [175-178], (2) the radial migration for cells moving away from the tangential routes into the CP [99]

Migration and Lamination of Cortical Interneurons and (3) the ventricle-directed migration from the IZ/SVZ towards the VZ [179]. The second migratory mode encompasses both inward radial migration towards the $\mathrm{CP}$ from the MZ $[31,175,176]$ and outward radial migration towards the CP from the IZ/SVZ [31, 176, 177, 180].

Using flat-mount cortical preparations and real-time microscopy, several groups observed that a substantial proportion of embryonic GABAergic neurons exhibit the multidirectional migration, where the cells move in all directions within the MZ $[175,176]$ and VZ [177]. Furthermore, Tanaka et al. [178] suggest that GABAergic cells, once reaching the $\mathrm{MZ}$, are liberated from regulation by guidance signals and appear to change direction unpredictably, in a process they term 'random walk'. The random walk behaviour potentially contributes to the spread of interneurons throughout the cortex; however, we know that the cortex is not uniform and cortical regions vary in interneuron number and subtype content [49]. If this is the case, the distribution of interneurons is not entirely random, but guided to a certain extent by extrinsic or intrinsic signals. Interestingly, Cajal-Retzius cells display multidirectional orientation comparable to the leading neurite angle of interneurons located in close proximity [175]; thus, Cajal-Retzius cells may provide positional cues for migrating interneurons. Furthermore, as Cajal-Retzius cells play a role in early regionalization of the cerebral cortical neuro-epithelium [181], it is tempting to speculate that they can also influence the patterning of the cortical interneurons.

The invasion of the CP by MGE-derived neurons from both the IZ (moving outward) and from the MZ (moving inward) has been shown using in vitro transplantation studies [31] or in vivo with the glutamic acid decarboxylase 67 (GAD67)-green fluorescent protein (GFP) knockin line [176-178]. GAD67 is an interneuron-specific enzyme required for GABA synthesis, and the GAD67-GFP knockin line has been instrumental for real-time imaging of interneuron migration in cortical slices. Tanaka et al. [178] propose that MGE-derived interneurons migrate first to the cortical SVZ, then from the SVZ to the CP, accumulating transiently in the MZ. The existence of this outward migration was confirmed and identified as being characteristic of late-born interneurons (after E15.5) [180]. Finally, there is evidence that cortical interneurons may migrate inwardly towards the VZ, in what has been termed 'ventricle-directed migration', perhaps to receive signals that may ultimately assist them in correctly integrating into the cortex [179].

It has been suggested that the switch from tangential to radial migration is dependent on neurite branching 
dynamics. While migrating in the tangential migratory streams, interneurons maintain the orientation of the leading neurite parallel to the ventricular surface/pia. Interneurons may linger in the migratory streams for long periods of time [178] before receiving the signal to move into the CP. Once received, the angle of the leading branch changes from small to nearly orthogonal, and the switch from tangential to a radial migratory mode is achieved [99]. From what we know about the guidance-directed migratory behaviour exhibited by interneurons, any cue governing a switch to radial migration needs to be highly regulated both spatially and temporally during corticogenesis.

The molecular cues governing this switch in trajectory are still largely unknown; however, some possible candidates have been identified. The downregulation of connexin 43 expression in interneurons significantly decreased the percentage of radially oriented cells, with a concomitant increase in tangential cell orientation [182]. These studies also verified that the adhesive function of connexin 43 , and not formation of hemichannels, was required for interaction with the radial glia. Another regulator, the HMG-box-containing transcription factor Sox6 plays a role as loss of Sox6 in MGE-derived cells causes an accumulation of interneurons in the MZ. This has been interpreted as a defect in the transition from tangential to radial migration $[83,84]$.

Another approach to control radial migration could be the downregulation of cues required for anchoring interneurons in the MZ during the horizontal dispersion phase. This is observed with the chemokine CXCL12 and its receptors CXCR4 and CXCR7. As described above, CXCL12 expression in the MZ and SVZ [143] is thought to attract cortical interneurons [145]. Loss of CXCL12 signalling increases interneuron branching [183] and dramatically disrupts tangential migration $[144,145,184-$ 188], resulting in the premature entry of interneurons into the CP and abnormal lamination (fig. 3a). Thus, CXCL12/CXCR signalling may play a dual role, initially attracting interneurons to the neocortex and subsequently maintaining their migration in the tangential streams until the correct radial signal is received.

Other examples of signalling systems required to maintain interneurons in the tangential streams include the interaction between netrin 1 and $\alpha_{3} \beta_{1}$-integrin. An increase in the number of cells switching from tangential to radial migration is observed when this interaction is perturbed [189]. Finally, a possible role for Cajal-Retzius cell and pyramidal neuron involvement is hinted at in the nestin-BDNF transgenic mouse where inappropriate seg- regation of Cajal-Retzius cells and altered cortical organization impair the final radial migration of interneurons [125]. Considerable progress has been made in recent years regarding radial migration, and future studies will help illuminate other factors involved in this essential process.

\section{Interneuron Lamination}

The characteristic 6-layered structure of the mature mammalian cortex is formed largely through the radial migration of the pyramidal neurons. During early cortical development, the first wave of postmitotic pyramidal neurons moves rapidly from the VZ/SVZ to the pial surface, forming a thin mantle layer of cortical primordium called the preplate layer. A second wave of neurons splits the preplate layer into the superficial layer I (MZ) and a deeper SP layer, establishing the CP in between. The CP is then expanded in an 'inside-out' manner, with layer VI forming first, and subsequent waves of neurons migrating past their predecessors to form the more superficial layers (layers V to II) [190-193].

Although cortical interneurons approach the $\mathrm{CP}$ from a subcortical source, it is believed that a similar inside-out pattern of lamination occurs, with early-born cells occupying deeper layers and late-born cells populating superficial layers [108, 175, 180, 193-196]. There are, however, exceptions to this rule as it was observed that the earlyborn cells actually occupy 2 peak locations, a large peak around layer V and a minor peak around layer II/III [197]. Further studies in the rat found that while PV-positive cells did follow the inside-out layering pattern, CR-positive cells followed an outside-in route, with early-born cells located in layer II/III and late-born cells in layers VVI [198]. It has since become apparent that the final destination of interneurons in the $\mathrm{CP}$ is not solely dependent on the time of generation, but is also subject to the site of origin. While cells derived from the MGE follow the location of the pyramidal cells born at the same time $[60,70$, 195], CGE-derived cells primarily populate the outer cortical layers regardless of when they are generated [27, 28, 57, 199, 200] (fig. 3b).

\section{Cues Controlling Interneuron Lamination}

Cortical lamination in the mouse begins around E11 and is completed by approximately postnatal day 14. Interestingly, although a small number of interneurons have been observed moving in and out of the $\mathrm{CP}$ at early stages of corticogenesis [31, 175-177], they do not become 
established in their correct layer until late embryonic/early postnatal stages, well after their contemporaneously born pyramidal neuron counterparts $[180,200]$. It has been suggested that cues from the cortex, rather than intrinsic genetic programming, controls interneuron lamination $[195,201]$ (table 1). One well-known molecule thought to play a major role in cortical lamination is the secreted extracellular matrix protein reelin. Loss of reelin signalling reverses the lamination of the cortex to an outside-in pattern, whereby late-born pyramidal neurons are unable to migrate past the early-born cells [180, 191]. Abnormal interneuron layering is also observed with disrupted reelin signalling (fig. 3b) [180, 200, 202, 203]; however, there is some contention to whether this is the direct action of reelin or a secondary effect of disorganized pyramidal neuron layering. Work by Hammond et al. [203] suggests that the laminar position of late-born interneurons (not early-born) is dependent on reelin signalling, whereas Pla et al. [200] found that interneurons were dependent on the location of pyramidal neurons and not reelin signalling. Both studies utilized chimeric models of transplanting wild-type cells into a Dabl mutant (intracellular adaptor molecule for reelin signalling), and even though their interpretations differ, one underlying phenomenon remains the same: the influence of pyramidal neurons on directing interneurons into the appropriate laminar position.

This line of reasoning has been explored recently in an elegant study by Lodato et al. [204]. Analysis of the Fezf2 knockout revealed that the loss of subcerebral pyramidal neurons and replacement by callosal pyramidal neurons causes the abnormal distribution of specific interneuron subtypes (fig. 3b). Furthermore, they showed that different types of glutamatergic pyramidal neurons effectively recruit specific subtypes of interneurons into their immediate vicinity. Thus, it appears that the identity of a pyramidal neuron, as well as its location, can control the laminar fate of an interneuron. The molecular mechanisms used by pyramidal neurons in this attraction remain unknown.

A number of other signalling molecules have been shown to affect interneuron positioning in the cortex. Disruption in the glial derived neurotrophic factor receptor, GFR $\alpha_{1}$, causes the loss of a subset of PV-positive interneurons in discrete regions of the cortex, predominantly in the visual and frontal cortices [128]. Abnormal interneuron lamination, and partial loss of PV- and SSTpositive interneurons, is also observed in p35 knockout mice [Rakic, Faux and Parnavelas, pers. commun., 108] (fig. 3b). During corticogenesis, p35 is the primary activa-

Migration and Lamination of Cortical Interneurons tor of Cdk5, a serine-threonine kinase, which phosphorylates proteins associated with the cytoskeleton and thereby plays a pivotal role in neuronal migration [205, 206]. Disruptions to the tangential and radial migration of the cells, for example by disrupting the CXCL12/ CXCR4 and BDNF/TrkB signalling pathways, can also greatly affect their laminar position $[125,145,184,187$, 189]. Furthermore, neuronal activity has been shown to affect interneuron layering postnatally. Overexpression of the potassium channel Kir2.1 alters neuronal excitability by lowering the resting membrane potential of the cell. When induced between postnatal days 0-3 in CGE-derived interneurons, an aberrant increase in CR- and reelin-positive cells is observed in deeper cortical layers and morphological alterations only after postnatal day 5 [96]. Therefore, it is clear that lamination is influenced by multiple mechanisms which we have only just begun to identify.

\section{The Stop Signal}

In comparison to our current, albeit limited, knowledge of the signals involved in lamination, even less is known about the cues that direct an interneuron to stop migration in the correct laminar position and to start arborization. One study, by Bortone and Polleux [207], has suggested that interneurons stop migrating in response to GABA, but only after the interneuron has switched from a depolarizing to a hyperpolarizing state in response to GABA activation. This switch in responsiveness follows the upregulation of the potassium/chloride exchanger KCC2 [208]. Low levels of KCC2 expression force the cell into a depolarizing state following GABA stimulation promoting cell migration. An increase in KCC2 expression reverses the electrochemical potential by extruding chloride ions from the neuron. This results in GABAstimulated hyperpolarization and causes the cell to stop migrating. The observed upregulation of KCC2 was nonsynchronous, thus making it difficult to determine precisely which interneuron subtypes terminate migration first [207]. It has recently been shown, however, that MGE-derived interneurons upregulate their KCC2 expression before CGE-derived cells, suggesting that MGEderived subpopulations stop radial migration before CGE-derived cells [199]. Many questions remain regarding the termination of interneuron migration, such as what regulates KCC2 expression. Perhaps more intriguing, can various interneuron subtypes respond differently to available intrinsic or extrinsic signals to promote termination and differentiation in defined laminar positions? These and many more questions will drive the in- 
terneuron field into the future, as we are only beginning to understand the intricacies of generating the functional balance between pyramidal neurons and interneurons.

\section{Neurodevelopmental Disorders and Interneuron Development}

In the adult brain, interneurons play a vital role in modulating neuronal excitability and the generation of temporal synchrony and oscillation among networks of glutamatergic neurons. This role is depicted in an eloquent analogy by $\mathrm{Di}$ Cristo [209] 'to compare interneuron function to the music director of a symphony orchestra, who structures and coordinates the overall musical performance. Without proper direction, the ensemble cannot produce the right melody'. Dysfunction in GABA neurotransmission is believed to be the aetiological basis for a variety of neuropsychiatric disorders such as schizophrenia, autism spectrum disorders, epilepsy and mood disorders [210-214]. This is evidenced by either loss of interneuron numbers, calcium-binding protein characteristics or alterations in synaptic receptors.

In simplistic terms there are 4 possible explanations for a loss in GABA function in a diseased brain. First, loss of a precursor population would significantly reduce the number of interneurons and, depending on the precursor, may reduce these numbers in a subtype-specific manner. Second, perturbations in signalling mechanisms regulating migration, lamination or differentiation will reduce the number and function of integrated interneurons. Third, interneurons may locate in the correct laminar position at birth but become abnormal as maturation proceeds. This reflects the protracted development of GABA circuits occurring over the first two decades of life [215]. Fourth, input of extrinsic fibre systems that continue until the early adult period, such as the dopaminergic afferents, may develop abnormally and delay or prevent interneuron maturation [216]. We will present the following discussion from an embryonic perspective and reflect on abnormal interneuron lamination in relation to signalling pathways we have described previously to be involved with migration.

We have only just begun to appreciate the influence of pyramidal neurons on interneuron development and the link between genes regulating migration of both neurons. The genetic analysis of human brain malformations has identified mutations in 2 genes, Lisl (also known as $P A F A H 1 \beta 1$ ) and $D c x$, which result in a pyramidal migratory disturbance known as type 1 lissencephaly, literally meaning 'smooth brain' [217]. This condition is characterized by a 4-layered cortex, with no obvious relationship to the normal 6 layers, in addition to gyral abnormalities that present as a smooth exterior. Historically, mutations in Lisl and Dcx are associated with abnormal pyramidal neuron migration, but more recently these proteins have been associated with interneuron migration in rodents $[106,107]$. The investigation of interneuron defects in several human cases of agyria has revealed a substantial reduction in the number of cortical, but not brain stem and cerebellum interneurons [218]. A significant reduction in the number of CR-positive interneurons is also noted in Miller-Dieker syndrome (LIS1 mutation) [219]. Human mutations in the transcription factor Arx, which is necessary for the Dlx-dependent promotion of interneuron migration, are associated with neurological disorders including lissencephaly, mental retardation and epilepsy (X-linked lissencephaly associated with abnormal genitalia, XLAG syndrome). These conditions display aberrant migration and differentiation of interneurons [220], and many of the neurological phenotypes observed in patients can be attributed to interneuron dysfunction.

A deficit in GABA transmission is among the most consistent findings in schizophrenia patients, and these exhibit a degree of interneuron subtype specificity. A number of detailed studies on post-mortem tissue have revealed a decrease in PV-positive interneurons [221,222] or a global decrease in GAD67 in the dorsal lateral prefrontal cortex [223-225]. It remains unclear if particular subtypes are more vulnerable in a schizophrenic brain, and one line of evidence proposes an increased susceptibility of fast-spiking PV-positive interneurons to the redox dysfunction exhibited in a schizophrenic brain [226]. Moreover, to further characterize changes in the dorsal lateral prefrontal cortex, a recent study has revealed lamina-specific alterations in the GABA $\alpha_{1^{-}}$and $\beta_{2}$-receptor subunits expressed by interneurons [224]. This places emphasis on the impairment of microcircuits rather than global cortical circuits as a causal factor in disease progression.

The identification of susceptible genes by association and gene linkage studies represent a major advance in investigating the aetiology of schizophrenia. One candidate gene, NRG1 with its receptor ErbB4, has reproducibly transpired as being a candidate gene across differing ethnic groups [151-155]. The rodent studies previously described have shown a role for NRG1 during migration, where type III regulates interneurons locally in the GE, whereas type I and II signal from the cortex and promote 
migration. ErbB4 is expressed in interneurons $[148,227]$ and analysis of the ErbB4 knockout mouse shows a reduction of 50 and $30 \%$ of the cortical and hippocampal interneurons, respectively $[146,228]$. Interestingly, in the adult hippocampus there was a selective loss of interneurons positive for PV and neuronal nitric oxide synthase, but not SST-positive interneurons which have negligible levels of ErbB4 [229]. From a developmental perspective, all 3 interneurons are generated in the MGE; however, NRG1 is required for the survival of only particular subtypes that are also absent in the human condition.

\section{Concluding Remarks}

Our current understanding of the cellular and molecular mechanisms involved in the migration and specification of interneurons is based on decades of research. Together with advances in new technologies, like genetic fate mapping (for the identification of the multiple interneuron subtypes) and high-resolution in vivo imaging, there is great promise to enhance our understanding of interneuron development. In particular, researchers are starting to tackle the intricate issues, such as the influence exerted by pyramidal neurons over different facets of interneuron migration. Questions relating to interneuron lamination, starting with the switch from a tangential to a radial mode of migration, to the subtype-specific positioning of the interneurons with their pyramidal counterparts, are beginning to be addressed. In the years to come, characterization of changes in specific subclasses of interneurons in schizophrenia and other psychiatric disorders will provide important insights into the observed GABAergic dysfunction. Moreover, the evolutionary adaptation of distinct interneuron origins in humans, as well as the existence of additional subtypes, may help to elucidate the potential causes of many neurological conditions. Although simultaneous studies in rodents disclose comparable cues required for human interneuron development, we must bear in mind that the genesis of subtypes specific to higher primates may not be imitated in the rodent model. Thus, like the interneurons themselves, although we have travelled a long way in our journey to decipher the complexities of interneuron development, the path is still long, and there is still much to be learned and ultimately gained.

\section{References}

$\checkmark 1$ Finlay BL, Darlington RB: Linked regularities in the development and evolution of mammalian brains. Science 1995;268:15781584.

-2 Goldman-Rakic PS: Regional and cellular fractionation of working memory. Proc Natl Acad Sci USA 1996;93:13473-13480.

3 Kawaguchi Y, Kubota Y: Neurochemical features and synaptic connections of large physiologically identified GABAergic cells in the rat frontal cortex. Neuroscience 1998;85: 677-701.

$\checkmark 4$ Thomson AM, Bannister AP: Interlaminar connections in the neocortex. Cereb Cortex 2003;13:5-14

$>5$ Tamamaki N, Tomioka R: Long-range GABAergic connections distributed throughout the neocortex and their possible function. Front Neurosci 2010;4:202.

-6 Sernagor E, Chabrol F, Bony G, Cancedda L: GABAergic control of neurite outgrowth and remodeling during development and adult neurogenesis: general rules and differences in diverse systems. Front Cell Neurosci 2010;4:11.

7 Corbin JG, Butt SJ: Developmental mechanisms for the generation of telencephalic interneurons. Dev Neurobiol 2011;71:710-732.
8 Fishell G, Rudy B: Mechanisms of inhibition within the telencephalon: 'where the wild things are'. Annu Rev Neurosci 2011;34:535567.

9 Gelman DM, Marin O: Generation of interneuron diversity in the mouse cerebral cortex. Eur J Neurosci 2010;31:2136-2141.

10 Mione MC, Danevic C, Boardman P, Harris B, Parnavelas JG: Lineage analysis reveals neurotransmitter (GABA or glutamate) but not calcium-binding protein homogeneity in clonally related cortical neurons. J Neurosci 1994; 14:107-123.

11 Parnavelas JG, Barfield JA, Franke E, Luskin $\mathrm{MB}$ : Separate progenitor cells give rise to pyramidal and nonpyramidal neurons in the rat telencephalon. Cereb Cortex 1991;1:463468.

$\$ 12$ Price J, Thurlow L: Cell lineage in the rat cerebral cortex: a study using retroviral-mediated gene transfer. Development 1988;104: 473-482.

13 Van Eden CG, Mrzljak L, Voorn P, Uylings HB: Prenatal development of GABA-ergic neurons in the neocortex of the rat. J Comp Neurol 1989;289:213-227.

14 Walsh C, Cepko CL: Widespread dispersion of neuronal clones across functional regions of the cerebral cortex. Science 1992;255:434440 .
15 Tan SS, Breen S: Radial mosaicism and tangential cell dispersion both contribute to mouse neocortical development. Nature 1993;362:638-640.

16 De Carlos JA, Lopez-Mascaraque L, Valverde F: Dynamics of cell migration from the lateral ganglionic eminence in the rat. J Neurosci 1996;16:6146-6156.

17 Lavdas AA, Grigoriou M, Pachnis V, Parnavelas JG: The medial ganglionic eminence gives rise to a population of early neurons in the developing cerebral cortex. J Neurosci 1999;19:7881-7888.

18 Tamamaki N, Fujimori KE, Takauji R: Origin and route of tangentially migrating neurons in the developing neocortical intermediate zone. J Neurosci 1997; 17:8313-8323.

-19 Anderson SA, Eisenstat DD, Shi L, Rubenstein JL: Interneuron migration from basal forebrain to neocortex: dependence on $D l x$ genes. Science 1997;278:474-476.

20 Wu S, Esumi S, Watanabe K, Chen J, Nakamura KC, Nakamura K, Kometani K, Minato N, Yanagawa Y, Akashi K, Sakimura K, Kaneko T, Tamamaki N: Tangential migration and proliferation of intermediate progenitors of GABAergic neurons in the mouse telencephalon. Development 2011;138:24992509 . 
21 Nery S, Fishell G, Corbin JG: The caudal ganglionic eminence is a source of distinct cortical and subcortical cell populations. Nat Neurosci 2002;5:1279-1287.

-22 Wichterle H, Garcia-Verdugo JM, Herrera DG, Varez-Buylla A: Young neurons from medial ganglionic eminence disperse in adult and embryonic brain. Nat Neurosci 1999;2:461-466.

23 Wichterle H, Turnbull DH, Nery S, Fishell G, Varez-Buylla A: In utero fate mapping reveals distinct migratory pathways and fates of neurons born in the mammalian basal forebrain. Development 2001;128:37593771.

24 Yozu M, Tabata H, Nakajima K: The caudal migratory stream: a novel migratory stream of interneurons derived from the caudal ganglionic eminence in the developing mouse forebrain. J Neurosci 2005;25:7268-7277.

25 Nery S, Corbin JG, Fishell G: Dlx2 progenitor migration in wild type and $\mathrm{Nkx} 2.1 \mathrm{mu}-$ tant telencephalon. Cereb Cortex 2003;13: 895-903.

-26 Sussel L, Marin O, Kimura S, Rubenstein JL: Loss of Nkx2.1 homeobox gene function results in a ventral to dorsal molecular respecification within the basal telencephalon: evidence for a transformation of the pallidum into the striatum. Development 1999; 126:3359-3370.

27 Miyoshi G, Hjerling-Leffler J, Karayannis T, Sousa VH, Butt SJ, Battiste J, Johnson JE, Machold RP, Fishell G: Genetic fate mapping reveals that the caudal ganglionic eminence produces a large and diverse population of superficial cortical interneurons. J Neurosci 2010;30:1582-1594.

-28 Rubin AN, Alfonsi F, Humphreys MP, Choi CK, Rocha SF, Kessaris N: The germinal zones of the basal ganglia but not the septum generate GABAergic interneurons for the cortex. J Neurosci 2010;30:12050-12062.

-29 Kanatani S, Yozu M, Tabata H, Nakajima K: COUP-TFII is preferentially expressed in the caudal ganglionic eminence and is involved in the caudal migratory stream. J Neurosci 2008;28:13582-13591.

-30 Anderson SA, Marin O, Horn C, Jennings K, Rubenstein JL: Distinct cortical migrations from the medial and lateral ganglionic eminences. Development 2001;128:353-363.

- 31 Polleux F, Whitford KL, Dijkhuizen PA, Vitalis T, Ghosh A: Control of cortical interneuron migration by neurotrophins and PI3-kinase signaling. Development 2002 129:3147-3160.

- 32 Jimenez D, Lopez-Mascaraque LM, Valverde F, De Carlos JA: Tangential migration in neocortical development. Dev Biol 2002;244: 155-169.

-33 Gelman DM, Martini FJ, Nobrega-Pereira S, Pierani A, Kessaris N, Marin O: The embryonic preoptic area is a novel source of cortical GABAergic interneurons. J Neurosci 2009; 29:9380-9389.
34 Riccio O, Murthy S, Szabo G, Vutskits L, Kiss JZ, Vitalis T, Lebrand C, Dayer AG: New pool of cortical interneuron precursors in the early postnatal dorsal white matter. Cereb Cortex 2012;22:86-98.

35 Defelipe J: The evolution of the brain, the human nature of cortical circuits, and intellectual creativity. Front Neuroanat 2011;5:29.

36 Jones EG: Varieties and distribution of nonpyramidal cells in the somatic sensory cortex of the squirrel monkey. J Comp Neurol 1975; 160:205-267.

37 Letinic K, Zoncu R, Rakic P: Origin of GABAergic neurons in the human neocortex. Nature 2002;417:645-649.

38 Casarosa S, Fode C, Guillemot F: Mash1 regulates neurogenesis in the ventral telencephalon. Development 1999;126:525-534.

39 Long JE, Cobos I, Potter GB, Rubenstein JL: Dlx1 \& 2 and Mash1 transcription factors control MGE and CGE patterning and differentiation through parallel and overlapping pathways. Cereb Cortex 2009;19(suppl 1):i96-i106.

40 Hansen DV, Lui JH, Parker PR, Kriegstein AR: Neurogenic radial glia in the outer subventricular zone of human neocortex. $\mathrm{Na}$ ture 2010;464:554-561.

41 Parras CM, Hunt C, Sugimori M, Nakafuku M, Rowitch D, Guillemot F: The proneural gene Mash1 specifies an early population of telencephalic oligodendrocytes. J Neurosci 2007;27:4233-4242.

42 Petanjek Z, Berger B, Esclapez M: Origins of cortical GABAergic neurons in the cynomolgus monkey. Cereb Cortex 2009; 19:249262.

43 Rakic S, Zecevic N: Emerging complexity of layer I in human cerebral cortex. Cereb Cortex 2003;13:1072-1083.

44 Jakovcevski I, Mayer N, Zecevic N: Multiple origins of human neocortical interneurons are supported by distinct expression of transcription factors. Cereb Cortex 2010;21: 1771-1782.

45 Zecevic N, Hu F, Jakovcevski I: Cortical interneurons in the developing human neocortex. Dev Neurobiol 2010, E-pub ahead of print.

46 Yu X, Zecevic N: Dorsal radial glial cells have the potential to generate cortical interneurons in human but not in mouse brain. J Neurosci 2011;31:2413-2420.

47 Fertuzinhos S, Krsnik Z, Kawasawa YI, Rasin MR, Kwan KY, Chen JG, Judas M, Hayashi M, Sestan N: Selective depletion of molecularly defined cortical interneurons in human holoprosencephaly with severe striatal hypoplasia. Cereb Cortex 2009;19:21962207.

53 Kubota Y, Shigematsu N, Karube F, Sekigawa A, Kato S, Yamaguchi N, Hirai Y, Morishima M, Kawaguchi Y: Selective coexpression of multiple chemical markers defines discrete populations of neocortical GABAergic neurons. Cereb Cortex 2011;21:1803-1817.

54 Chow A, Erisir A, Farb C, Nadal MS, Ozaita A, Lau D, Welker E, Rudy B: $\mathrm{K}^{+}$channel expression distinguishes subpopulations of parvalbumin- and somatostatin-containing neocortical interneurons. J Neurosci 1999; 19:9332-9345.

55 Weiser M, Bueno E, Sekirnjak C, Martone ME, Baker H, Hillman D, Chen S, Thornhill W, Ellisman M, Rudy B: The potassium channel subunit KV3.1b is localized to somatic and axonal membranes of specific populations of CNS neurons. J Neurosci 1995; 15:4298-4314.

56 Lee S, Hjerling-Leffler J, Zagha E, Fishell G, Rudy B: The largest group of superficial neocortical GABAergic interneurons expresses ionotropic serotonin receptors. J Neurosci 2010;30:16796-16808.

57 Vucurovic K, Gallopin T, Ferezou I, Rancillac A, Chameau P, van Hooft JA, Geoffroy $\mathrm{H}$, Monyer H, Rossier J, Vitalis T: Serotonin 3a receptor subtype as an early and protracted marker of cortical interneuron subpopulations. Cereb Cortex 2010;20:2333-2347.

$\checkmark 58 \mathrm{Xu}$ X, Roby KD, Callaway EM: Immunochemical characterization of inhibitory mouse cortical neurons: three chemically distinct classes of inhibitory cells. J Comp Neurol 2010;518:389-404. 
59 Gonchar Y, Wang Q, Burkhalter A: Multiple distinct subtypes of GABAergic neurons in mouse visual cortex identified by triple immunostaining. Front Neuroanat 2007;1:3.

60 Miyoshi G, Butt SJ, Takebayashi H, Fishell G: Physiologically distinct temporal cohorts of cortical interneurons arise from telencephalic olig2-expressing precursors. J Neurosci 2007;27:7786-7798.

-61 Kawaguchi Y, Kubota Y: Physiological and morphological identification of somatostatin- or vasoactive intestinal polypeptidecontaining cells among GABAergic cell subtypes in rat frontal cortex. J Neurosci 1996; 16:2701-2715.

-62 Ma Y, Hu H, Berrebi AS, Mathers PH, Agmon A: Distinct subtypes of somatostatincontaining neocortical interneurons revealed in transgenic mice. J Neurosci 2006 26:5069-5082.

63 Karagiannis A, Gallopin T, David C, Battaglia D, Geoffroy H, Rossier J, Hillman EM, Staiger JF, Cauli B: Classification of NPY-expressing neocortical interneurons. J Neurosci 2009;29:3642-3659.

-64 Eisenstat DD, Liu JK, Mione M, Zhong W, Yu G, Anderson SA, Ghattas I, Puelles L, Rubenstein JL: Dlx-1, Dlx-2, and Dlx-5 expression define distinct stages of basal forebrain differentiation. J Comp Neurol 1999;414:217237.

65 Ghanem N, Yu M, Long J, Hatch G, Rubenstein JL, Ekker M: Distinct cis-regulatory elements from the Dlx1/Dlx2 locus mark different progenitor cell populations in the ganglionic eminences and different subtypes of adult cortical interneurons. J Neurosci 2007; 27:5012-5022.

66 Cobos I, Broccoli V, Rubenstein JL: The vertebrate ortholog of aristaless is regulated by $D l x$ genes in the developing forebrain. J Comp Neurol 2005;483:292-303.

67 Briscoe J, Sussel L, Serup P, HartiganO’Connor D, Jessell TM, Rubenstein JL, Ericson J: Homeobox gene $N k x 2.2$ and specification of neuronal identity by graded sonic hedgehog signalling. Nature 1999;398:622627.

68 Flames N, Pla R, Gelman DM, Rubenstein JL, Puelles L, Marin O: Delineation of multiple subpallial progenitor domains by the combinatorial expression of transcriptional codes. J Neurosci 2007;27:9682-9695.

69 Flandin P, Zhao Y, Vogt D, Jeong J, Long J, Potter G, Westphal H, Rubenstein JL: Lhx6 and Lhx8 coordinately induce neuronal expression of Shh that controls the generation of interneuron progenitors. Neuron 2011;70: 939-950.

70 Butt SJ, Fuccillo M, Nery S, Noctor S, Kriegstein A, Corbin JG, Fishell G: The temporal and spatial origins of cortical interneurons predict their physiological subtype. Neuron 2005;48:591-604.

Migration and Lamination of Cortical Interneurons
71 Fogarty M, Grist M, Gelman D, Marin O, Pachnis V, Kessaris N: Spatial genetic patterning of the embryonic neuroepithelium generates GABAergic interneuron diversity in the adult cortex. J Neurosci 2007;27: 10935-10946.

72 Xu Q, Cobos I, De La Cruz E, Rubenstein JL, Anderson SA: Origins of cortical interneuron subtypes. J Neurosci 2004;24:2612-2622.

73 Wonders CP, Taylor L, Welagen J, Mbata IC, Xiang JZ, Anderson SA: A spatial bias for the origins of interneuron subgroups within the medial ganglionic eminence. Dev Biol 2008; 314:127-136

74 Inan M, Welagen J, Anderson SA: Spatial and temporal bias in the mitotic origins of somatostatin- and parvalbumin-expressing interneuron subgroups and the chandelier subtype in the medial ganglionic eminence. Cereb Cortex 2011, E-pub ahead of print.

75 Xu Q, Guo L, Moore H, Waclaw RR, Campbell K, Anderson SA: Sonic hedgehog signaling confers ventral telencephalic progenitors with distinct cortical interneuron fates. Neuron 2010;65:328-340.

76 Yu W, Wang Y, McDonnell K, Stephen D, Ba CB: Patterning of ventral telencephalon requires positive function of Gli transcription factors. Dev Biol 2009;334:264-275.

$77 \mathrm{Xu}$ Q, Wonders CP, Anderson SA: Sonic hedgehog maintains the identity of cortical interneuron progenitors in the ventral telencephalon. Development 2005;132:49874998.

78 Jessell TM: Neuronal specification in the spinal cord: inductive signals and transcriptional codes. Nat Rev Genet 2000;1:20-29.

-79 Butt SJ, Sousa VH, Fuccillo MV, HjerlingLeffler J, Miyoshi G, Kimura S, Fishell G: The requirement of $\mathrm{Nkx} 2-1$ in the temporal specification of cortical interneuron subtypes. Neuron 2008;59:722-732.

80 Cobos I, Calcagnotto ME, Vilaythong AJ, Thwin MT, Noebels JL, Baraban SC, Rubenstein JL: Mice lacking Dlx1 show subtypespecific loss of interneurons, reduced inhibition and epilepsy. Nat Neurosci 2005;8: 1059-1068.

81 Lodato S, Tomassy GS, De Leonibus E, Uzcategui YG, Andolfi G, Armentano M, Touzot A, Gaztelu JM, Arlotta P, Menendez de la Prida L, Studer M: Loss of COUP-TFI alters the balance between caudal ganglionic eminence- and medial ganglionic eminence-derived cortical interneurons and results in resistance to epilepsy. J Neurosci 2011;31: 4650-4662.

82 Cubelos B, Sebastian-Serrano A, Kim S, Re dondo JM, Walsh C, Nieto M: Cux-1 and Cux-2 control the development of reelin expressing cortical interneurons. Dev Neurobiol 2008;68:917-925.

83 Batista-Brito R, Rossignol E, Hjerling-Leffler J, Denaxa M, Wegner M, Lefebvre V, Pachnis V, Fishell G: The cell-intrinsic requirement of Sox6 for cortical interneuron development. Neuron 2009;63:466-481.
84 Azim E, Jabaudon D, Fame RM, Macklis JD: Sox6 controls dorsal progenitor identity and interneuron diversity during neocortical development. Nat Neurosci 2009;12:12381247.

85 Wang Y, Dye CA, Sohal V, Long JE, Estrada RC, Roztocil T, Lufkin T, Deisseroth K, Baraban SC, Rubenstein JL: Dlx5 and Dlx6 regulate the development of parvalbumin-expressing cortical interneurons. J Neurosci 2010;30:5334-5345.

- 86 Sousa VH, Miyoshi G, Hjerling-Leffler J, Karayannis T, Fishell G: Characterization of Nkx6-2-derived neocortical interneuron lineages. Cereb Cortex 2009;19(suppl 1):i1i10.

87 Liodis P, Denaxa M, Grigoriou M, AkufoAddo C, Yanagawa Y, Pachnis V: Lhx6 activity is required for the normal migration and specification of cortical interneuron subtypes. J Neurosci 2007;27:3078-3089.

88 Molyneaux BJ, Arlotta P, Menezes JR, Macklis JD: Neuronal subtype specification in the cerebral cortex. Nat Rev Neurosci 2007;8: 427-437.

89 Mukhopadhyay A, McGuire T, Peng CY, Kessler JA: Differential effects of BMP signaling on parvalbumin and somatostatin interneuron differentiation. Development 2009;136:2633-2642.

90 Grosse G, Djalali S, Deng DR, Holtje M, Hinz B, Schwartzkopff K, Cygon M, Rothe T, Stroh T, Hellweg R, Ahnert-Hilger G, Hortnag H: Area-specific effects of brain-derived neurotrophic factor (BDNF) genetic ablation on various neuronal subtypes of the mouse brain. Brain Res Dev Brain Res 2005;156: 111-126.

91 Fiumelli H, Kiraly M, Ambrus A, Magistretti PJ, Martin JL: Opposite regulation of calbindin and calretinin expression by brainderived neurotrophic factor in cortical neurons. J Neurochem 2000;74:1870-1877.

92 Ageta-Ishihara N, Takemoto-Kimura S, Nonaka M, Adachi-Morishima A, Suzuki K, Kamijo S, Fujii H, Mano T, Blaeser F, Chatila TA, Mizuno H, Hirano T, Tagawa Y, Okuno $\mathrm{H}$, Bito $\mathrm{H}$ : Control of cortical axon elongation by a GABA-driven $\mathrm{Ca}^{2+} /$ calmodulindependent protein kinase cascade. J Neurosci 2009;29:13720-13729.

93 Brennaman LH, Maness PF: Developmental regulation of GABAergic interneuron branching and synaptic development in the prefrontal cortex by soluble neural cell adhesion molecule. Mol Cell Neurosci 2008;37: 781-793.

94 Chattopadhyaya B, Di Cristo G, Wu CZ, Knott G, Kuhlman S, Fu Y, Palmiter RD, Huang ZJ: Gad67-mediated GABA synthesis and signaling regulate inhibitory synaptic innervation in the visual cortex. Neuron 2007;54:889-903. 
-95 Jin X, Hu H, Mathers PH, Agmon A: Brainderived neurotrophic factor mediates activity-dependent dendritic growth in nonpyramidal neocortical interneurons in developing organotypic cultures. J Neurosci 2003;23:5662-5673.

96 De Marco Garcia NV, Karayannis T, Fishell G: Neuronal activity is required for the development of specific cortical interneuron subtypes. Nature 2011;472:351-355.

97 Britto JM, Obata K, Yanagawa Y, Tan SS: Migratory response of interneurons to different regions of the developing neocortex. Cereb Cortex 2006; 16(suppl 1):i57-i63.

$\$ 98$ Bellion A, Baudoin JP, Alvarez C, Bornens M, Metin C: Nucleokinesis in tangentially migrating neurons comprises two alternating phases: forward migration of the Golgi/ centrosome associated with centrosome splitting and myosin contraction at the rear. J Neurosci 2005;25:5691-5699.

-99 Martini FJ, Valiente M, Lopez Bendito G, Szabo G, Moya F, Valdeolmillos M, Marin $\mathrm{O}$ : Biased selection of leading process branches mediates chemotaxis during tangential neuronal migration. Development 2009;136:41-50.

100 Alvarez-Buylla A, Garcia-Verdugo JM: Neurogenesis in adult subventricular zone. J Neurosci 2002;22:629-634.

101 Schaar BT, McConnell SK: Cytoskeletal coordination during neuronal migration. Proc Natl Acad Sci USA 2005;102:1365213657.

102 Britto JM, Johnston LA, Tan SS: The stochastic search dynamics of interneuron migration. Biophys J 2009;97:699-709.

103 Martini FJ, Valdeolmillos M: Actomyosin contraction at the cell rear drives nuclear translocation in migrating cortical interneurons. J Neurosci 2010;30:8660-8670.

104 Tsai JW, Bremner KH, Vallee RB: Dual subcellular roles for Lis1 and dynein in radial neuronal migration in live brain tissue. Nat Neurosci 2007;10:970-979.

105 Gopal PP, Simonet JC, Shapiro W, Golden JA: Leading process branch instability in Lis1+/- nonradially migrating interneurons. Cereb Cortex 2010;20:1497-1505.

- 106 Kappeler C, Saillour Y, Baudoin JP, Tuy FP, Alvarez C, Houbron C, Gaspar P, Hamard G, Chelly J, Metin C, Francis F: Branching and nucleokinesis defects in migrating interneurons derived from doublecortin knockout mice. Hum Mol Genet 2006;15: 1387-1400.

107 Friocourt G, Liu JS, Antypa M, Rakic S, Walsh CA, Parnavelas JG: Both doublecortin and doublecortin-like kinase play a role in cortical interneuron migration. J Neurosci 2007;27:3875-3883.

108 Rakic S, Yanagawa Y, Obata K, Faux C, Parnavelas JG, Nikolic M: Cortical interneurons require $\mathrm{p} 35 / \mathrm{Cdk} 5$ for their migration and laminar organization. Cereb Cortex 2009;19:1857-1869.
109 Tanaka T, Serneo FF, Tseng HC, Kulkarni AB, Tsai LH, Gleeson JG: Cdk5 phosphorylation of doublecortin Ser297 regulates its effect on neuronal migration. Neuron 2004;41:215-227.

110 Corbin JG, Nery S, Fishell G: Telencephalic cells take a tangent: non-radial migration in the mammalian forebrain. Nat Neurosci 2001;4(suppl):1177-1182.

111 Marin O, Rubenstein JL: Cell migration in the forebrain. Annu Rev Neurosci 2003;26: 441-483.

112 Metin C, Baudoin JP, Rakic S, Parnavelas JG: Cell and molecular mechanisms involved in the migration of cortical interneurons. Eur J Neurosci 2006;23:894-900.

113 Faux C, Rakic S, Andrews W, Yanagawa Y, Obata K, Parnavelas JG: Differential gene expression in migrating cortical interneurons during mouse forebrain development. J Comp Neurol 2010;518:1232-1248.

114 Marsh ED, MinarcikJ, Campbell K, BrooksKayal AR, Golden JA: Facs-array gene expression analysis during early development of mouse telencephalic interneurons. Dev Neurobiol 2008;68:434-445.

115 Powell EM, Mars WM, Levitt P: Hepatocyte growth factor/scatter factor is a motogen for interneurons migrating from the ventral to dorsal telencephalon. Neuron 2001; 30:79-89.

116 Friedman WJ, Black IB, Kaplan DR: Distribution of the neurotrophins brain-derived neurotrophic factor, neurotrophin-3, and neurotrophin-4/5 in the postnatal rat brain: an immunocytochemical study. Neuroscience 1998;84:101-114.

117 Fukumitsu H, Furukawa Y, Tsusaka M, Kinukawa $H$, Nitta A, Nomoto $H$, Mima T, Furukawa S: Simultaneous expression of brain-derived neurotrophic factor and neurotrophin-3 in Cajal-Retzius, subplate and ventricular progenitor cells during early development stages of the rat cerebral cortex. Neuroscience 1998;84:115-127.

118 Maisonpierre PC, Belluscio L, Friedman B, Alderson RF, Wiegand SJ, Furth ME, Lindsay RM, Yancopoulos GD: NT-3, BDNF and NGF in the developing rat nervous system: parallel as well as reciprocal patterns of expression. Neuron 1990;5:501-509.

119 Timmusk T, Belluardo N, Metsis M, Persson H: Widespread and developmentally regulated expression of neurotrophin-4 mRNA in rat brain and peripheral tissues. Eur J Neurosci 1993;5:605-613.

120 Gorba T, Wahle P: Expression of Trkb and Trkc but not BDNF mRNA in neurochemically identified interneurons in rat visual cortex in vivo and in organotypic cultures. Eur J Neurosci 1999;11:1179-1190.

121 Klein R, Martin-Zanca D, Barbacid M, Parada LF: Expression of the tyrosine kinase receptor gene Trkb is confined to the murine embryonic and adult nervous system. Development 1990;109:845-850.
122 Shinoda Y, Sadakata T, Nakao K, KatohSemba R, Kinameri E, Furuya A, Yanagawa Y, Hirase H, Furuichi T: Calcium-dependent activator protein for secretion 2 (CAPS2) promotes BDNF secretion and is critical for the development of GABAergic interneuron network. Proc Natl Acad Sci USA 2011;108:373-378.

123 Arenas E, Akerud P, Wong V, Boylan C, Persson H, Lindsay RM, Altar CA: Effects of BDNF and NT-4/5 on striatonigral neuropeptides or nigral GABA neurons in vivo. Eur J Neurosci 1996;8:1707-1717.

124 Jones KR, Farinas I, Backus C, Reichardt LF: Targeted disruption of the BDNF gene perturbs brain and sensory neuron development but not motor neuron development. Cell 1994;76:989-999.

125 Alcantara S, Pozas E, Ibanez CF, Soriano E: BDNF-modulated spatial organization of Cajal-Retzius and GABAergic neurons in the marginal zone plays a role in the development of cortical organization. Cereb Cortex 2006;16:487-499.

126 Pozas E, Ibanez CF: GDNF and GFRalphal promote differentiation and tangential migration of cortical GABAergic neurons. Neuron 2005;45:701-713.

127 Airaksinen MS, Saarma M: The GDNF family: signalling, biological functions and therapeutic value. Nat Rev Neurosci 2002; 3:383-394.

128 Canty AJ, Dietze J, Harvey M, Enomoto H, Milbrandt J, Ibanez CF: Regionalized loss of parvalbumin interneurons in the cerebral cortex of mice with deficits in GFRalpha1 signaling. J Neurosci 2009;29:1069510705.

129 Marin O, Yaron A, Bagri A, Tessier-Lavigne M, Rubenstein JL: Sorting of striatal and cortical interneurons regulated by semaphorin-neuropilin interactions. Science 2001;293:872-875.

130 Zimmer G, Schanuel SM, Burger S, Weth F, Steinecke A, Bolz J, Lent R: Chondroitin sulfate acts in concert with semaphorin $3 \mathrm{a}$ to guide tangential migration of cortical interneurons in the ventral telencephalon. Cereb Cortex 2010;20:2411-2422.

-131 Tamamaki N, Fujimori K, Nojyo Y, Kaneko T, Takauji R: Evidence that Sema3a and Sema3f regulate the migration of GABAergic neurons in the developing neocortex. J Comp Neurol 2003;455:238-248.

-132 Bagri A, Marin O, Plump AS, Mak J, Pleasure SJ, Rubenstein JL, Tessier-Lavigne M: Slit proteins prevent midline crossing and determine the dorsoventral position of major axonal pathways in the mammalian forebrain. Neuron 2002;33:233-248.

133 Marillat V, Cases O, Nguyen-Ba-Charvet KT, Tessier-Lavigne M, Sotelo C, Chedotal A: Spatiotemporal expression patterns of Slit and Robo genes in the rat brain. J Comp Neurol 2002;442:130-155. 


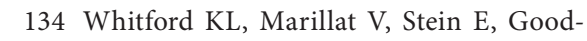
man CS, Tessier-Lavigne M, Chedotal A, Ghosh A: Regulation of cortical dendrite development by Slit-Robo interactions. Neuron 2002;33:47-61.

-135 Yuan W, Zhou L, Chen JH, Wu JY, Rao Y, Ornitz DM: The mouse Slit family: secreted ligands for Robo expressed in patterns that suggest a role in morphogenesis and axon guidance. Dev Biol 1999;212:290-306.

-136 Andrews W, Barber M, Hernandez-Miranda LR, Xian J, Rakic S, Sundaresan V, Rabbitts TH, Pannell R, Rabbitts P, Thompson H, Erskine L, Murakami F, Parnavelas JG: The role of Slit-Robo signaling in the generation, migration and morphological differentiation of cortical interneurons. Dev Biol 2008;313:648-658.

-137 Andrews W, Liapi A, Plachez C, Camurri L, Zhang J, Mori S, Murakami F, Parnavelas JG, Sundaresan V, Richards LJ: Robol regulates the development of major axon tracts and interneuron migration in the forebrain. Development 2006;133:2243-2252.

-138 Andrews WD, Barber M, Parnavelas JG: Slit-Robo interactions during cortical development. J Anat 2007;211:188-198.

139 Barber M, Di Meglio T, Andrews WD, Hernandez-Miranda LR, Murakami F, Chedotal A, Parnavelas JG: The role of Robo3 in the development of cortical interneurons. Cereb Cortex 2009;19(suppl 1):i22-i31.

140 Hernandez-Miranda LR, Cariboni A, Faux C, Ruhrberg C, Cho JH, Cloutier JF, Eickholt BJ, Parnavelas JG, Andrews WD: Robol regulates semaphorin signaling to guide the migration of cortical interneurons through the ventral forebrain. J Neurosci 2011;31:6174-6187.

141 Zimmer G, Garcez P, Rudolph J, Niehage R, Weth F, Lent R, Bolz J: Ephrin-a5 acts as a repulsive cue for migrating cortical interneurons. Eur J Neurosci 2008;28:62-73.

142 Rudolph J, Zimmer G, Steinecke A, Barchmann S, Bolz J: Ephrins guide migrating cortical interneurons in the basal telencephalon. Cell Adh Migr 2010;4:400-408.

143 Tiveron MC, Rossel M, Moepps B, Zhang YL, Seidenfaden R, Favor J, Konig N, Cremer H: Molecular interaction between projection neuron precursors and invading interneurons via stromal-derived factor 1 (CXCL12)/CXCR4 signaling in the cortical subventricular zone/intermediate zone. J Neurosci 2006;26:13273-13278.

- 144 Sanchez-Alcaniz JA, Haege S, Mueller W, Pla R, Mackay F, Schulz S, Lopez-Bendito G, Stumm R, Marin O: CXCR7 controls neuronal migration by regulating chemokine responsiveness. Neuron 2011;69:7790.

- 145 Li G, Adesnik H, Li J, Long J, Nicoll RA, Rubenstein JL, Pleasure SJ: Regional distribution of cortical interneurons and development of inhibitory tone are regulated by CXCL12/CXCR4 signaling. J Neurosci 2008;28:1085-1098.
146 Flames N, Long JE, Garratt AN, Fischer TM, Gassmann M, Birchmeier C, Lai C, Rubenstein JL, Marin O: Short- and longrange attraction of cortical GABAergic interneurons by neuregulin-1. Neuron 2004; 44:251-261.

147 Ying G, Wu S, Hou R, Huang W, Capecchi $\mathrm{MR}, \mathrm{Wu} \mathrm{Q}$ : The protocadherin gene Celsr3 is required for interneuron migration in the mouse forebrain. Mol Cell Biol 2009;29: 3045-3061.

148 Gerecke KM, Wyss JM, Karavanova I, Buonanno A, Carroll SL: ErbB transmembrane tyrosine kinase receptors are differentially expressed throughout the adult rat central nervous system. J Comp Neurol 2001;433:86-100.

- 149 Yau HJ, Wang HF, Lai C, Liu FC: Neural development of the neuregulin receptor ErbB4 in the cerebral cortex and the hippocampus: preferential expression by interneurons tangentially migrating from the ganglionic eminences. Cereb Cortex 2003; 13:252-264.

150 Neddens J, Fish KN, Tricoire L, Vullhorst D, Shamir A, Chung W, Lewis DA, McBain CJ, Buonanno A: Conserved interneuronspecific ErbB4 expression in frontal cortex of rodents, monkeys, and humans: implications for schizophrenia. Biol Psychiatry 2011;70:636-645

151 Li D, Collier DA, He L: Meta-analysis shows strong positive association of the neuregulin 1 (NRG1) gene with schizophrenia. Hum Mol Genet 2006;15:1995-2002.

152 Munafo MR, Thiselton DL, Clark TG, Flint J: Association of the NRG1 gene and schizophrenia: a meta-analysis. Mol Psychiatry 2006;11:539-546.

153 Nicodemus KK, Luna A, Vakkalanka R, Goldberg T, Egan M, Straub RE, Weinberger DR: Further evidence for association between ErbB4 and schizophrenia and influence on cognitive intermediate phenotypes in healthy controls. Mol Psychiatry 2006;11:1062-1065.

154 Silberberg G, Darvasi A, Pinkas-Kramarski R, Navon R: The involvement of ErbB4 with schizophrenia: association and expression studies. Am J Med Genet B Neuropsychiatr Genet 2006;141B:142-148.

-155 Stefansson H, Sigurdsson E, Steinthorsdottir V, Bjornsdottir S, Sigmundsson T, Ghosh S, Brynjolfsson J, Gunnarsdottir S, Ivarsson O, Chou TT, Hjaltason O, Birgisdottir B, Jonsson H, Gudnadottir VG, Gudmundsdottir $\mathrm{E}$, Bjornsson A, Ingvarsson B, Ingason A, Sigfusson S, Hardardottir H, Harvey RP, Lai D, Zhou M, Brunner D, Mutel V, Gonzalo A, Lemke G, Sainz J, Johannesson G, Andresson T, Gudbjartsson D, Manolescu A, Frigge ML, Gurney ME, Kong A, Gulcher JR, Petursson H, Stefansson K: Neuregulin 1 and susceptibility to schizophrenia. Am J Hum Genet 2002;71:877892.
156 Alifragis P, Liapi A, Parnavelas JG: Lhx6 regulates the migration of cortical interneurons from the ventral telencephalon but does not specify their GABA phenotype. J Neurosci 2004;24:5643-5648.

157 Friocourt G, Kanatani S, Tabata H, Yozu M, Takahashi T, Antypa M, Raguenes O, Chelly J, Ferec C, Nakajima K, Parnavelas JG: Cell-autonomous roles of ARX in cell proliferation and neuronal migration during corticogenesis. J Neurosci 2008;28: 5794-5805.

158 Colasante G, Collombat P, Raimondi V, Bonanomi D, Ferrai C, Maira M, Yoshikawa K, Mansouri A, Valtorta F, Rubenstein JL, Broccoli V: ARX is a direct target of Dlx2 and thereby contributes to the tangential migration of GABAergic interneurons. J Neurosci 2008;28:10674-10686.

159 Zhao Y, Flandin P, Long JE, Cuesta MD, Westphal H, Rubenstein JL: Distinct molecular pathways for development of telencephalic interneuron subtypes revealed through analysis of Lhx6 mutants. J Comp Neurol 2008;510:79-99.

160 Cobos I, Borello U, Rubenstein JL: Dlx transcription factors promote migration through repression of axon and dendrite growth. Neuron 2007;54:873-888.

161 Le TN, Du G, Fonseca M, Zhou QP, Wigle JT, Eisenstat DD: Dlx homeobox genes promote cortical interneuron migration from the basal forebrain by direct repression of the semaphorin receptor neuropilin-2. J Biol Chem 2007;282:19071-19081.

$162 \mathrm{Du}$ T, Xu Q, Ocbina PJ, Anderson SA: Nkx2.1 specifies cortical interneuron fate by activating Lhx6. Development 2008; 135: 1559-1567.

163 Nobrega-Pereira S, Kessaris N, Du T, Kimura S, Anderson SA, Marin O: Postmitotic Nkx2-1 controls the migration of telencephalic interneurons by direct repression of guidance receptors. Neuron 2008;59:733745.

164 Cuzon VC, Yeh PW, Cheng Q, Yeh HH: Ambient GABA promotes cortical entry of tangentially migrating cells derived from the medial ganglionic eminence. Cereb Cortex 2006;16:1377-1388.

165 Lopez-Bendito G, Lujan R, Shigemoto R, Ganter P, Paulsen O, Molnar Z: Blockade of $\mathrm{GABA}_{\mathrm{B}}$ receptors alters the tangential migration of cortical neurons. Cereb Cortex 2003;13:932-942.

166 Cuzon Carlson VC, Yeh HH: $\mathrm{GABA}_{\mathrm{A}}$ receptor subunit profiles of tangentially $\mathrm{mi}-$ grating neurons derived from the medial ganglionic eminence. Cereb Cortex 2011; 21:1792-1802.

167 Crandall JE, McCarthy DM, Araki KY, Sims JR, Ren JQ, Bhide PG: Dopamine receptor activation modulates GABA neuron migration from the basal forebrain to the cerebral cortex. J Neurosci 2007;27:38133822. 
-168 Ohtani N, Goto T, Waeber C, Bhide PG: Dopamine modulates cell cycle in the lateral ganglionic eminence. J Neurosci 2003;23: 2840-2850.

169 Metin C, Denizot JP, Ropert N: Intermediate zone cells express calcium-permeable AMPA receptors and establish close contact with growing axons. J Neurosci 2000; 20:696-708.

170 Poluch S, Drian MJ, Durand M, Astier C, Benyamin Y, Konig N: AMPA receptor activation leads to neurite retraction in tangentially migrating neurons in the intermediate zone of the embryonic rat neocortex. J Neurosci Res 2001;63:35-44.

-171 Soria JM, Valdeolmillos M: Receptor-activated calcium signals in tangentially migrating cortical cells. Cereb Cortex 2002; 12:831-839.

-172 Owens DF, Liu X, Kriegstein AR: Changing properties of $\mathrm{GABA}_{\mathrm{A}}$ receptor-mediated signaling during early neocortical development. J Neurophysiol 1999;82:570-583.

-173 Araki T, Kiyama H, Tohyama M: GABA receptor subunit messenger RNAs show differential expression during cortical development in the rat brain. Neuroscience 1992;51:583-591.

174 Souza BR, Romano-Silva MA, Tropepe V: Dopamine $\mathrm{D}_{2}$ receptor activity modulates Akt signaling and alters GABAergic neuron development and motor behavior in zebrafish larvae. J Neurosci 2011;31:55125525.

-175 Ang ES Jr, Haydar TF, Gluncic V, Rakic P: Four-dimensional migratory coordinates of gabaergic interneurons in the developing mouse cortex. J Neurosci 2003;23:58055815.

-176 Tanaka D, Nakaya Y, Yanagawa Y, Obata K, Murakami F: Multimodal tangential migration of neocortical GABAergic neurons independent of GPI-anchored proteins. Development 2003;130:5803-5813.

- 177 Tanaka DH, Maekawa K, Yanagawa Y, Obata K, Murakami F: Multidirectional and multizonal tangential migration of GABAergic interneurons in the developing cerebral cortex. Development 2006;133:21672176.

-178 Tanaka DH, Yanagida M, Zhu Y, Mikami S, Nagasawa T, Miyazaki J, Yanagawa Y, Obata K, Murakami F: Random walk behavior of migrating cortical interneurons in the marginal zone: time-lapse analysis in flatmount cortex. J Neurosci 2009;29:13001311.

-179 Nadarajah B, Alifragis P, Wong RO, Parnavelas JG: Ventricle-directed migration in the developing cerebral cortex. Nat Neurosci 2002;5:218-224.

180 Hevner RF, Daza RA, Englund C, Kohtz J, Fink A: Postnatal shifts of interneuron position in the neocortex of normal and reeler mice: evidence for inward radial migration. Neuroscience 2004;124:605-618.
81 Griveau A, Borello U, Causeret F, Tissir F, Boggetto N, Karaz S, Pierani A: A novel role for Dbx1-derived Cajal-Retzius cells in early regionalization of the cerebral cortical neuroepithelium. PLoS Biol 2010; 8:e1000440.

182 Elias LA, Turmaine M, Parnavelas JG, Kriegstein AR: Connexin 43 mediates the tangential to radial migratory switch in ventrally derived cortical interneurons. J Neurosci 2010;30:7072-7077.

183 Lysko DE, Putt M, Golden JA: SDF1 regulates leading process branching and speed of migrating interneurons. J Neurosci 2011; 31:1739-1745

184 Lopez-Bendito G, Sanchez-Alcaniz JA, Pla R, Borrell V, Pico E, Valdeolmillos M, Marin O: Chemokine signaling controls intracortical migration and final distribution of GABAergic interneurons. J Neurosci 2008;28:1613-1624.

185 Wang Y, Li G, Stanco A, Long JE, Crawford D, Potter GB, Pleasure SJ, Behrens T, Rubenstein JL: CXCR4 and CXCR7 have distinct functions in regulating interneuron migration. Neuron 2011;69:61-76.

186 Stumm RK, Zhou C, Ara T, Lazarini F, Dubois-Dalcq M, Nagasawa T, Hollt V, Schulz $\mathrm{S}$ : CXCR4 regulates interneuron migration in the developing neocortex. J Neurosci 2003;23:5123-5130.

187 Tanaka DH, Mikami S, Nagasawa T, Miyazaki J, Nakajima K, Murakami F: CXCR4 is required for proper regional and laminar distribution of cortical somatostatin-, calretinin-, and neuropeptide Y-expressing GABAergic interneurons. Cereb Cortex 2010;20:2810-2817.

188 Caronia-Brown G, Grove EA: Timing of cortical interneuron migration is influenced by the cortical hem. Cereb Cortex 2011;21:748-755.

189 Stanco A, Szekeres C, Patel N, Rao S, Campbell K, Kreidberg JA, Polleux F, Anton ES: Netrin-1- $\alpha 3 \beta 1$ integrin interactions regulate the migration of interneurons through the cortical marginal zone. Proc Natl Acad Sci USA 2009; 106:7595-7600.

190 Angevine JB Jr, Sidman RL: Autoradiographic study of cell migration during histogenesis of cerebral cortex in the mouse. Nature 1961;192:766-768.

191 Caviness VS Jr: Neocortical histogenesis in normal and reeler mice: a developmental study based upon $\left[{ }^{3} \mathrm{H}\right]$ thymidine autoradiography. Brain Res 1982;256:293-302.

192 Rakic P: Neurons in rhesus monkey visual cortex: systematic relation between time of origin and eventual disposition. Science 1974;183:425-427.

193 Fairen A, Cobas A, Fonseca M: Times of generation of glutamic acid decarboxylase immunoreactive neurons in mouse somatosensory cortex. J Comp Neurol 1986; 251:67-83.
194 Lopez-Bendito G, Sturgess K, Erdelyi F, Szabo G, Molnar Z, Paulsen O: Preferential origin and layer destination of GAD65GFP cortical interneurons. Cereb Cortex 2004; 14:1122-1133.

195 Valcanis H, Tan SS: Layer specification of transplanted interneurons in developing mouse neocortex. J Neurosci 2003;23:51135122.

196 Miller MW: The migration and neurochemical differentiation of gamma-aminobutyric acid (GABA)-immunoreactive neurons in rat visual cortex as demonstrated by a combined immunocytochemical-autoradiographic technique. Brain Res 1986;393: 41-46.

197 Yozu M, Tabata H, Nakajima K: Birth-date dependent alignment of GABAergic neurons occurs in a different pattern from that of non-GABAergic neurons in the developing mouse visual cortex. Neurosci Res 2004;49:395-403.

198 Rymar VV, Sadikot AF: Laminar fate of cortical GABAergic interneurons is dependent on both birthdate and phenotype. J Comp Neurol 2007;501:369-380.

199 Miyoshi G, Fishell G: Gabaergic interneuron lineages selectively sort into specific cortical layers during early postnatal development. Cereb Cortex 2011;21:845-852.

200 Pla R, Borrell V, Flames N, Marin O: Layer acquisition by cortical gabaergic interneurons is independent of reelin signaling. J Neurosci 2006;26:6924-6934.

201 Poluch S, Jablonska B, Juliano SL: Alteration of interneuron migration in a ferret model of cortical dysplasia. Cereb Cortex 2008;18:78-92.

202 Yabut O, Renfro A, Niu S, Swann JW, Marin O, D’Arcangelo G: Abnormal laminar position and dendrite development of interneurons in the reeler forebrain. Brain Res 2007; 1140:75-83.

203 Hammond V, So E, Gunnersen J, Valcanis $\mathrm{H}$, Kalloniatis M, Tan SS: Layer positioning of late-born cortical interneurons is dependent on reelin but not p35 signaling. J Neurosci 2006;26:1646-1655.

- 204 Lodato S, Rouaux C, Quast KB, Jantrachotechatchawan C, Studer M, Hensch TK, Arlotta P: Excitatory projection neuron subtypes control the distribution of local inhibitory interneurons in the cerebral cortex. Neuron 2011;69:763-779.

205 Dhavan R, Tsai LH: A decade of CDK5. Nat Rev Mol Cell Biol 2001;2:749-759.

206 Tsai LH, Delalle I, Caviness VS Jr, Chae T, Harlow E: p35 is a neural-specific regulatory subunit of cyclin-dependent kinase 5 . Nature 1994;371:419-423.

207 Bortone D, Polleux F: KCC2 expression promotes the termination of cortical interneuron migration in a voltage-sensitive calcium-dependent manner. Neuron 2009;62: 53-71. 
208 Ben-Ari Y: Excitatory actions of GABA during development: the nature of the nurture. Nat Rev Neurosci 2002;3:728-739.

209 Di Cristo G: Development of cortical GABAergic circuits and its implications for neurodevelopmental disorders. Clin Genet 2007;72:1-8.

210 Belmonte MK, Cook EH Jr, Anderson GM, Rubenstein JL, Greenough WT, BeckelMitchener A, Courchesne E, Boulanger LM, Powell SB, Levitt PR, Perry EK, Jiang YH, De Lorey TM, Tierney E: Autism as a disorder of neural information processing: directions for research and targets for therapy. Mol Psychiatry 2004;9:646-663.

-211 Benes FM, Berretta S: GABAergic interneurons: implications for understanding schizophrenia and bipolar disorder. Neuropsychopharmacology 2001;25:1-27.

- 212 Lewis DA, Hashimoto T, Volk DW: Cortical inhibitory neurons and schizophrenia. Nat Rev Neurosci 2005;6:312-324.

213 Marco P, Sola RG, Pulido P, Alijarde MT, Sanchez A, Ramon y Cajal S, De Felipe J: Inhibitory neurons in the human epileptogenic temporal neocortex. An immunocytochemical study. Brain 1996;119:13271347.

214 Rubenstein JL: Three hypotheses for developmental defects that may underlie some forms of autism spectrum disorder. Curr Opin Neurol 2010;23:118-123.

215 Lewis DA, Levitt P: Schizophrenia as a disorder of neurodevelopment. Annu Rev Neurosci 2002;25:409-432.

216 Benes FM, Vincent SL, Molloy R, Khan Y: Increased interaction of dopamine-immunoreactive varicosities with GABA neurons of rat medial prefrontal cortex occurs during the postweanling period. Synapse 1996; 23:237-245.
217 Feng Y, Walsh CA: Protein-protein interactions, cytoskeletal regulation and neuronal migration. Nat Rev Neurosci 2001;2:408416.

218 Marcorelles P, Laquerriere A, Adde-Michel C, Marret S, Saugier-Veber P, Beldjord C, Friocourt G: Evidence for tangential migration disturbances in human lissencephaly resulting from a defect in LIS1, DCX and ARX genes. Acta Neuropathol 2010;120: 503-515.

219 Pancoast M, Dobyns W, Golden JA: Interneuron deficits in patients with the MillerDieker syndrome. Acta Neuropathol 2005; 109:400-404.

220 Okazaki S, Ohsawa M, Kuki I, Kawawaki H, Koriyama T, Ri S, Ichiba H, Hai E, Inoue T, Nakamura H, Goto Y, Tomiwa K, Yamano T, Kitamura K, Itoh M: Aristaless-related homeobox gene disruption leads to abnormal distribution of GABAergic interneurons in human neocortex: evidence based on a case of X-linked lissencephaly with abnormal genitalia (XLAG). Acta Neuropathol 2008;116:453-462.

221 Beasley CL, Reynolds GP: Parvalbuminimmunoreactive neurons are reduced in the prefrontal cortex of schizophrenics. Schizophr Res 1997;24:349-355.

222 Hashimoto T, Bazmi HH, Mirnics K, Wu Q, Sampson AR, Lewis DA: Conserved regional patterns of GABA-related transcript expression in the neocortex of subjects with schizophrenia. Am J Psychiatry 2008;165: 479-489.

223 Akbarian S, Kim JJ, Potkin SG, Hagman JO, Tafazzoli A, Bunney WE Jr, Jones EG: Gene expression for glutamic acid decarboxylase is reduced without loss of neurons in prefrontal cortex of schizophrenics. Arch Gen Psychiatry 1995;52:258-266.

224 Beneyto M, Abbott A, Hashimoto T, Lewis DA: Lamina-specific alterations in cortical $\mathrm{GABA}_{\mathrm{A}}$ receptor subunit expression in schizophrenia. Cereb Cortex 2011;21:9991011.
225 Guidotti A, Auta J, Davis JM, Di-GiorgiGerevini V, Dwivedi Y, Grayson DR, Impagnatiello F, Pandey G, Pesold C, Sharma $\mathrm{R}$, Uzunov D, Costa E: Decrease in reelin and glutamic acid decarboxylase 67 (GAD67) expression in schizophrenia and bipolar disorder: a postmortem brain study. Arch Gen Psychiatry 2000;57:1061-1069.

226 Do KQ, Cabungcal JH, Frank A, Steullet P, Cuenod M: Redox dysregulation, neurodevelopment, and schizophrenia. Curr Opin Neurobiol 2009;19:220-230.

227 Huang YZ, Won S, Ali DW, Wang Q, Tanowitz M, Du QS, Pelkey KA, Yang DJ, Xiong WC, Salter MW, Mei L: Regulation of neuregulin signaling by PSD-95 interacting with ErbB4 at CNS synapses. Neuron 2000;26:443-455.

228 Fisahn A, Neddens J, Yan L, Buonanno A: Neuregulin-1 modulates hippocampal gamma oscillations: implications for schizophrenia. Cereb Cortex 2009; 19:612618.

229 Neddens J, Buonanno A: Selective populations of hippocampal interneurons express ErbB4 and their number and distribution is altered in ErbB4 knockout mice. Hippocampus 2010;20:724-744.

230 Gulacsi AA, Anderson SA: Beta-cateninmediated Wnt signaling regulates neurogenesis in the ventral telencephalon. Nat Neurosci 2008;11:1383-1391.

231 Glickstein SB, Moore H, Slowinska B, Racchumi J, Suh M, Chuhma N, Ross ME: Selective cortical interneuron and GABA deficits in cyclin D2-null mice. Development 2007;134:4083-4093.

232 Zhong J, Kim HT, Lyu J, Yoshikawa K, Nakafuku M, Lu W: The Wnt receptor Ryk controls specification of GABAergic neurons versus oligodendrocytes during telencephalon development. Development 2011; 138:409-419. 